\title{
Changes in sub-cellular localisation of trophoblast and inner cell mass specific transcription factors during bovine preimplantation development
}

Zofia E Madeja ${ }^{1 *}$, Jaroslaw Sosnowski ${ }^{1}$, Kamila Hryniewicz', Ewelina Warzych ${ }^{1}$, Piotr Pawlak', Natalia Rozwadowska ${ }^{2}$, Berenika Plusa ${ }^{3}$ and Dorota Lechniak ${ }^{1}$

\begin{abstract}
Background: Preimplantation bovine development is emerging as an attractive experimental model, yet little is known about the mechanisms underlying trophoblast (TE)/inner cell mass (ICM) segregation in cattle. To gain an insight into these processes we have studied protein and mRNA distribution during the crucial stages of bovine development. Protein distribution of lineage specific markers OCT4, NANOG, CDX2 were analysed in 5-cell, 8-16 cell, morula and blastocyst stage embryos. ICM/TE mRNA levels were compared in hatched blastocysts and included: OCT4, NANOG, FN-1, KLF4, C-MYC, REX1, CDX2, KRT-18 and GATA6.

Results: At the mRNA level the observed distribution patterns agree with the mouse model. CDX2 and OCT4 proteins were first detected in 5-cell stage embryos. NANOG appeared at the morula stage and was located in the cytoplasm forming characteristic rings around the nuclei. Changes in sub-cellular localisation of OCT4, NANOG and CDX2 were noted from the 8-16 cell onwards. CDX2 initially co-localised with OCT4, but at the blastocyst stage a clear lineage segregation could be observed. Interestingly, we have observed in a small proportion of embryos (2\%) that CDX2 immunolabelling overlapped with mitotic chromosomes.

Conclusions: Cell fate specification in cattle become evident earlier than presently anticipated - around the time of bovine embryonic genome activation. There is an intriguing possibility that for proper lineage determination certain transcription factors (such as CDX2) may need to occupy specific regions of chromatin prior to its activation in the interphase nucleus. Our observation suggests a possible role of CDX2 in the process of epigenetic regulation of embryonic cell fate.
\end{abstract}

Keywords: Bovine blastocyst, ICM/TE lineage segregation, Cell fate, Gene expression patterns, CDX2, Mitotic retention

\section{Background}

Despite recent advances in developmental biology our understanding of cell fate decisions during preimplantation development of non-rodent mammals still remains limited. With growing prospects of the use of stem cell research in medicine and animal biotechnology, cell lineage formation in species of economic significance, such as cattle or sheep is of increasing interest. Sharing many similarities with human embryos, bovine embryos present an attractive model for investigating the fundamental mechanisms of

\footnotetext{
*Correspondence: zofia.madeja@jay.up.poznan.pl

'Department of Genetics and Animal Breeding, Poznan University of Life Sciences, Wolynska 33, Poznan 60-673, Poland

Full list of author information is available at the end of the article
}

early development. These include the timing of epigenetic reprogramming, the stage of the embryonic genome activation and the timing of development $[1,2]$.

During the initial stages of mammalian development two successive differentiation events lead to the segregation of the three committed cell lineages. The first event begins at the compacted morula stage, where the outer layer of cells segregates to become the epithelial trophectoderm (TE) that gives rise to the embryonic part of the placenta. The inner layer of cells (inner cell mass, ICM) will produce the embryonic lineages. The second round of segregation divides the ICM into primitive ectoderm, which gives rise to the epiblast (nascent embryo proper) and the primitive endoderm (PrE) that forms the extra-embryonic endoderm

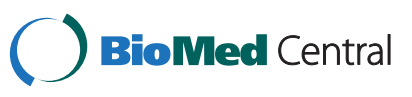


layer of the visceral yolk sac and in rodents also the parietal endoderm. The first cell fate decisions are governed by a combination of interactions between transcriptional networks, signalling, cell polarity and cell position within the morula [3]. At the cellular level the ICM/TE segregation is initiated by two rounds of differentiative divisions that result in spatially and molecularly distinct cell populations. The differentiation of TE may be regarded as the hallmark event in mammalian preimplantation development, as it is the first tissue that becomes differentiated during embryogenesis. Due to its biological function the ICM needs to retain its pluripotency status much longer, since the establishment of the three germ layers (endoderm, mesoderm, ectoderm) occurs soon after implantation in rodents and around day 14 in cattle [4]. In mice the process of TE formation initiates at the 8-cell stage, when embryos undergo compaction manifested by an increased intracellular adhesion, blastomere flattening and formation of adherens junctions [5]. Concurrent with this event, cells acquire an apical domain rich in proteins, such as the atypical protein kinase aPKC [6], the polarity protein Par3 [7] and the apical protein Erizn [8]. During the subsequent cell divisions (from 8-16 and from 16-32 cell stage) the differential inheritance of the apical, polarised surface determines either the TE or the ICM fate $[9,10]$.

At the molecular level the initiation of the TE lineage formation is promoted by the action of Tead4, which was shown to regulate multiple transcription factors important for trophoblast development $[11,12]$. Trophoblast maintenance depends on consecutive activation of factors such as caudal-type homeodomain transcription factor $2(\mathrm{Cdx} 2)$, trans-acting GATA binding transcription factor (Gata3), eomesodermin (Eomes) and epithelial-specific ETS factor (Elf5) ([13-18], rev. [19]). Cdx2 is the earliest known marker used to distinguish between mouse TE and ICM. Its expression begins at the 8-cell stage and becomes restricted to the outside cells at the time of blastocyst formation $[15,20]$. The polarity of the outer blastomeres is possibly the main factor responsible for up-regulation of $\mathrm{Cdx} 2$ expression in these cells [21]. Once Cdx2 expression becomes restricted to the outer cells, factors related to the maintenance of pluripotency and the ICM lineage formation are repressed. This action is maintained through a feedback loop regulated by Elf5 via the mutual suppression between $\mathrm{Cdx} 2$ and octamer binding transcription factor 3/4 (Oct3/4) and homeobox transcription factor (Nanog) complexes. Functional studies showed that $\mathrm{Cdx} 2$ blocks Oct3/4 activity in the TE committed cells, as in the presence of $\mathrm{Cdx} 2$, Oct $3 / 4$ occupied the heterochromatic regions of the nuclei [22]. More importantly, it was shown that Cdx2 can post-transcriptionally inactivate Oct4, thus TE commitment may occur before Oct 4 transcription is terminated $[22,23]$. The establishment of the ICM and the epiblast relies on the interactions of transcription factors
Oct4, Nanog, Sall4 and Sox2 ([24-27], rev. [28]). These factors are also key players in maintaining embryonic stem cell (ESC) pluripotency and possess an ability to auto-regulate their own transcription by sustaining a selfreinforcing transcriptional network. Sox 2 can synergistically act with Oct $3 / 4$ to activate Oct-Sox enhancers, which in turn regulate the expression of pluripotent stem cell specific genes such as Nanog, Oct3/4 and Sox2 [29]. Inactivation of Nanog results in peri-implantation lethality as mouse blastocysts fail to form the epiblast. Moreover, Nanog-null embryos exhibit a PrE marker Gata6 throughout the ICM [25,30] and knockdown of Nanog gene in mouse blastocysts and ESC resulted in an up-regulation of the TE specific genes (Cdx2 and Hand1) [31].

The unique molecular interactions underlying the ICM/ TE lineage specification in cow and other ungulate species still remains to be described in detail. The work by Berg et al. [32] shows that OCT4 expression in cattle TE may be retained until the PrE/epiblast segregation, indicating that the trophoblast cells may not become committed during bovine pre-implantation development at stages developmentally equivalent to the mouse. It was shown that at the early stages, CDX2 does not repress OCT4 expression, as the bovine OCT4 locus does not contain the cis-acting regulatory region necessary for extinguishing its transcription in TE [32]. Moreover, it was indicated that the TE cells of an early bovine blastocyst (7dpi) retain the ability to contribute to the ICM derivatives in chimeras [32]. It is therefore plausible that the standard ICM/TE markers described in the mouse become segregated at different (or later) stages during the ruminant embryo development.

Using cattle as a non-rodent model animal we have aimed to describe the mutual spatial allocation of factors that have been shown to be important for lineage commitment in the mouse. We have followed the specific distribution patterns from the very early stages of development, through the time of embryonic genome activation (EGA), until the hatched blastocyst $(\mathrm{HBl})$ stage. Contrary to what is claimed by the majority of published reports, we suggest that cell fate decisions in cattle may become initiated earlier than it is presently anticipated - around the time of embryonic genome activation. Of most interest our study indicates that CDX2 could possibly be subject to the phenomenon of mitotic retention, which may imply a role in epigenetic regulation of embryonic cell fate.

\section{Methods}

\section{In vitro production of bovine embryos (IVP)}

All procedures were performed in accordance with the guidelines of the National Ethical Commission for Animal Research (Ministry of Science and Higher Education, Poland). The study was approved by the Local Ethical 
Commission (dr Z.E. Madeja personal licence permit number: 142/2010).

Unless stated otherwise, all reagents used for IVP culture media preparation were supplied by Sigma-Aldrich, Poland. The media were made based on sterile embryo-tested water (Gibco, Life Technologies Poland).

Bovine cumulus-oocyte-complexes (COC) were collected from slaughterhouse ovaries. COCs were aspirated from 2-6 $\mathrm{mm}$ follicles, underwent a restrictive selection process [33] and were subjected to in vitro maturation (IVM). COCs were matured for 24 hours in TCM-199 medium containing $1 \mathrm{mg} / \mathrm{ml}$ fatty acid free BSA (fafBSA), $0.05 \mathrm{mg} /$ $\mathrm{ml}$ gentamycin, $0.022 \mathrm{mg} / \mathrm{ml}$ Na-pyruvate, $2.2 \mathrm{mg} / \mathrm{ml}$ $\mathrm{NaHCO}_{3}$ and hormones (5 UI/ml hCG, $10 \mathrm{UI} / \mathrm{ml}$ PMSG, Intervet) at $39^{\circ} \mathrm{C}$ in humidified atmosphere with $5 \% \mathrm{CO}_{2}$ (as described by Stinshoff et al. [34]). Insemination was done with bull sperm supplied by the Centre for Animal Breeding and Reproduction (Poznan, branch Tulce; 63-004 Tulce, Poland) at a concentration of $1 \times 10^{6} / \mathrm{ml}$. The sperm were washed twice by centrifugation and re-suspended in standard IVF-Sperm-Talp medium supplemented with $4 \mathrm{mg} / \mathrm{ml}$ fafBSA [35]. PHE (penicillin, hypotaurine, epinephrine) was used for sperm capacitation. After 20 hours of gamete co-incubation at $39^{\circ} \mathrm{C}$ in humidified atmosphere with $5 \% \mathrm{CO}_{2}$, the cumulus cells were mechanically removed by pipetting. The presumptive zygotes were transferred in groups of 10 to $30 \mu \mathrm{l}$ culture drops covered by embryo culture tested mineral oil. In vitro embryo culture (IVC) was carried out at $39^{\circ} \mathrm{C}$ in humidified atmosphere of $5 \% \mathrm{CO}_{2}, 5 \% \mathrm{O}_{2}, 90 \% \mathrm{~N}_{2}$ in a modular chamber placed inside an incubator. The IVC medium consisted of synthetic oviduct fluid culture medium (SOF) supplemented with essential and non-essential amino acids (MEM, BME) and $4 \mathrm{mg} / \mathrm{ml}$ fafBSA, as described by Holm et al. [36]. At 3 dpi the embryos were subjected to selection. Only cleaved embryos were placed in fresh IVC medium and were left in culture until they had reached the developmental stage required for the experiments.

\section{Embryo collection for qualitative and quantitative PCR analysis}

The selected material was washed with $0.25 \%$ polyvinylpirrolidone (PVP) in PBS placed in $1.5 \mathrm{ml}$ tubes in minimal volume, frozen in liquid nitrogen and stored in $-80^{\circ} \mathrm{C}$.

Qualitative gene expression analyses were performed on bovine embryos at $8-16$ cell stage, morula stage and hatched blastocysts (9dpi). 8-16 cell embryo samples were collected in pools, each consisting of 20 embryos. Morulae were collected in groups of 12 and 3 un-dissected blastocysts were pooled to make up one sample. We have collected 6 independent samples for each stage, collected over several IVP experiments. This allowed to eliminate the possible bias in gene expression analyses which could distort the results if all samples were collected during one IVP experiment.

Quantitative gene expression analysis were performed on hatched blastocysts $9 \mathrm{dpi}$. In order to reveal the possible differences in gene expression levels between the ICM and the TE, the blastocysts were microsurgically dissected. The ICMs made up one sample and the corresponding TEs made up the other sample. The ICM/TE samples were pooled in groups of 3 as we have empirically established that it was the lowest material content that allowed for efficient RNA extraction, cDNA synthesis and reliable real-time PCR analysis. In total we have collected 24 independent samples (12 ICM and $12 \mathrm{TE}$ ) from 72 embryos. For the means of quantitative calculations we have also collected 6 samples each containing 3 whole (un-dissected) HBls, that served as calibrators for the purpose of transcript quantification.

\section{RNA extraction and CDNA synthesis}

Total RNA was extracted from embryos using the High Pure miRNA Isolation Kit (Roche Diagnostics, Poland) according to the manufacturer's protocol. This kit was developed for the extraction of small RNA molecules, and it has proven to be an effective tool in extracting RNA from small copy number samples such as the preimplantation embryos. RNA concentration was measured on NanoDrop (Thermo Scientific, USA). For each sample reverse transcription was performed from $100 \mathrm{ng}$ of total RNA. cDNA synthesis was carried out with the Transcriptor High Fidelity cDNA Synthesis Kit (Roche Diagnostics) according to the manufacturer's protocol. The samples were stored in $-20^{\circ} \mathrm{C}$.

\section{Quantitative real-time RT-PCR analysis}

In short, we have compared the expression level of a certain gene in ICM and TE and related it to an un-dissected embryo. The experiments were performed on Roche Light Cycler 2.0 instrument. The calculations were based on relative gene expression data analyses using real-time PCR and the $2_{\mathrm{T}}^{-\Delta \Delta C}$ method as described by Livak and Schmittgen [37] and Schmittgen and Livak [38]. In order to establish the differences in gene expression levels between the ICM and the TE, the samples containing whole blastocysts served as reference points for relative gene expression level calculations. HBL was referred to as a calibrator. Gene expression levels were normalised to the expression level of the 18S rRNA gene that served as a reference. Each sample was subjected to gene expression analyses with all of the primer sets designed for the panel of chosen lineage specific genes and for the reference gene. All reactions were repeated in triplicates. The primers were designed to span the two neighbouring exons (Table 1). The reactions were carried out in $10 \mu \mathrm{l}$ capillaries (Roche Diagnostics) and the PCR mix comprised of $1 \mu \mathrm{l}$ 
Table 1 Primer pairs and annealing conditions used for the real-time PCR gene expression analyses

\begin{tabular}{lllcc}
\hline Name & Sense primer & Antisense primer & Product size & Annealing temperature \\
\hline CDX2 & CTITCCTCCGGATGGTGATA & AGCCAAGTGAAACCAGGAC & $113 \mathrm{bp}$ & $58^{\circ} \mathrm{C}$ \\
FN1 & TGGACGCTAGATTCCTTCG & GCTGCTGCTGGTGGTAGAAG & $155 \mathrm{bp}$ & $58^{\circ} \mathrm{C}$ \\
KLF4 & GCACTATGGCCAAAGAGAGG & AACAGGAGACAAGGGTGGG & $109 \mathrm{bp}$ & $58^{\circ} \mathrm{C}$ \\
KRT18 & AAACCAAAGAGGGAAGACG & ATGTGTAAGGGAGGTGTC & $291 \mathrm{bp}$ & $58^{\circ} \mathrm{C}$ \\
NANOG & GAGATCGAGGCTCTCAAGGA & GTCCAGCTCCTCTCGGTTCT & $201 \mathrm{bp}$ & $58^{\circ} \mathrm{C}$ \\
OCT4 & AAACAACTGGCCGAGGATA & AGGAGTGGTGCTCCAAGAC & $194 \mathrm{bp}$ & $58^{\circ} \mathrm{C}$ \\
GATA6 & GTTTGAGGCTTGGAGCTC & CTCCAGGTTGCTCTCACTC & $185 \mathrm{bp}$ & $58^{\circ} \mathrm{C}$ \\
REX1 & CTGCGGTCTCTACAGCAAGA & GTGGTCGTGTGTGACAGTT & $117 \mathrm{bp}$ & $58^{\circ} \mathrm{C}$ \\
185 rRNA & GGAAGAGGACCCACTCCTTC & ACTTGGCTCCTAGTGCATC & $241 \mathrm{bp}$ & $58^{\circ} \mathrm{C}$ \\
\hline
\end{tabular}

of Light Cycler Fast Start DNA master SYBR Green (Roche Diagnostics), $5 \mathrm{mM} \mathrm{MgCl}_{2}$ (Roche Diagnostics), $0.3 \mu \mathrm{M}$ of primers and $1 \mu \mathrm{l}$ of cDNA. Real-time PCR reaction conditions included: initial polymerase activation at $95^{\circ} \mathrm{C}$ for $10 \mathrm{~min}$, followed by 42 cycles of denaturation at $95^{\circ} \mathrm{C}$ for $10 \mathrm{~s}$, annealing (primer specific, listed in Table 1) for $10 \mathrm{~s}$, elongation at $72^{\circ} \mathrm{C}$ for $20 \mathrm{~s}$. Product specificity was confirmed by melting analysis.

\section{Statistical analysis}

A certain level of heterogeneity was noted within the analysed sample groups, thus the data did not follow normal distribution. Therefore to analyse statistically significant variability in gene expression levels between ICM and TE, the Wilcoxon signed-rank test was applied. Due to the nature of the experiment (number of repeats of each individual sample within one group - ICM/TE) the data was processed as median and presented as \pm SEM. Differences of $\mathrm{P}<0.05$ were considered significant. The mRNA data expression was analysed using the statistical package SPSS 17.0.

\section{Whole mount immunofluorescence}

The material included embryos at stages crucial for bovine development: 5-cell, 8-16-cell (bovine embryonic genome activation), morula (compaction) and blastocysts at various developmental stages - early blastocyst (7dpi), expanding blastocyst (8dpi) and hatched blastocyst (9dpi) as classified by Rekik et al. [39]. The embryos were selected during the same IVP experiments as the material collected for qualitative and quantitative gene expression analyses (Table 2).

From embryos of developmental stages earlier than HBL, zona pellucida (ZP) was removed prior to fixation by a brief incubation in acid Tyrode's solution supplemented with $0.1 \mathrm{~N} \mathrm{HCl}$. The embryos were processed as follows: briefly washed in PBS (pH 7.3) and fixed with 4\% paraformaldehyde in PBS with $0.1 \%$ Triton X-100 and $0.1 \%$
Tween20 (pH 8.0) for $15 \mathrm{~min}$ at $39^{\circ} \mathrm{C}$ (Sigma Aldrich). Immunofluorescent protein labeling was carried out as previously described by Madeja et al. [40] and Plusa et al. [41] with some modifications: permeabilisation with $0.55 \%$ Triton X-100/PBS for $20 \mathrm{~min}$; blocking of non-specific antibody binding with 10\% fetal calf serum in PBS, $60 \mathrm{~min}$ at room temperature (RT); three washes in $0.1 \%$ Triton $\mathrm{X}-100 / \mathrm{PBS}$ (PTX); overnight incubation with primary antibodies (ABI) diluted 1:50 in blocking buffer at $4^{\circ} \mathrm{C}$; three washes in PTX; blocking for $40 \mathrm{~min}$ at RT; secondary antibody (ABII) incubation at 1:200 dilution; three washes in PTX; embryo mounting on concave glass slides in $40 \mu \mathrm{l}$ drop containing antifade solution with DAPI (Vectashield mounting medium, Vector Laboratories, USA). The slides were stored at $+4^{\circ} \mathrm{C}$.

To avoid cross-reactivity between the $A B$ hosts the embryos were double labeled with various sets of $A B I$ and ABII. The primary antibody set included: anti-CDX2 mouse monoclonal AB (Abcam, UK, ab15258) or rabbit polyclonal AB (Abcam, ab88129); anti-OCT4 rabbit polyclonal AB (Abcam, ab18976) or goat polyclonal AB (Abcam, ab27985); anti-NANOG rabbit polyclonal AB (PeproTech, UK, 500-P236), anti-trimethyl-histone H3 (Lys9) AB (Merck-Millipore, 07-442). The secondary antibody set consisted of Santa Cruz Biotechnology, USA, ABII: donkey anti-goat Rhodamine conjugated AB (sc2094) or donkey anti-goat FITC conjugated AB (sc-2024), donkey anti-mouse Rhodamine conjugated AB (sc-2300); donkey anti-rabbit FITC conjugated (sc-2090), chicken anti-rabbit Rhodamine conjugated AB (sc-2862), chicken anti-mouse FITC conjugated AB (sc-2989); goat antimouse Rhodamine conjugated AB (sc-2092), goat antimouse FITC conjugated AB (sc-2010), goat anti-rabbit Rhodamine conjugated AB (sc-2091), goat anti-rabbit, FITC conjugated (sc-2012). Blocking peptide for CDX2: Abcam (ab99158). Fluorescent signals were visualized using a Zeiss Axiovert 200 M laser scanning confocal microscope. 
Table 2 Experimental groups and antibody set-up for single and double immunolabelling

\begin{tabular}{|c|c|c|c|c|c|c|}
\hline $\begin{array}{l}\text { Developmental } \\
\text { Stage }\end{array}$ & 5 -cell (n) & 8-16 cell $(n)$ & Morula (n) & $\begin{array}{l}\text { Blastocyst } \\
\text { 7dpi (n) }\end{array}$ & $\begin{array}{l}\text { Blastocyst } \\
\text { 8/9dpi (n) }\end{array}$ & $\begin{array}{l}\text { Hatched } \\
\text { Blastocyst } \\
\text { 9dpi (n) }\end{array}$ \\
\hline \multirow{10}{*}{$\begin{array}{l}\text { Number of immunostained embryos } \\
\text { per staining set-up ( } n)\end{array}$} & & & & $1(5)$ & & $1(5)$ \\
\hline & & & $1(4)$ & $2(4)$ & & $2(5)$ \\
\hline & $1(10)$ & $1(5)$ & $2(4)$ & $3(4)$ & & $3(6)$ \\
\hline & $2(10)$ & $2(4)$ & $3(4)$ & $4(4)$ & & $4(5)$ \\
\hline & $3(10)$ & $3(4)$ & $4(4)$ & $5(4)$ & $6(5)$ & $5(6)$ \\
\hline & $4(10)$ & $4(4)$ & $6(6)$ & $6(9)$ & $7(5)$ & $6(12)$ \\
\hline & $5(10)$ & $5(5)$ & $8(4)$ & $7(8)$ & $10(10)$ & $7(11)$ \\
\hline & & $9(20)$ & $9(11)$ & $8(6)$ & & $8(13)$ \\
\hline & & & $10(5)$ & $9(4)$ & & $9(10)$ \\
\hline & & & & $10(8)$ & & $10(12)$ \\
\hline \multirow[t]{5}{*}{ Antibody staining set-up } & \multicolumn{3}{|c|}{1 - CDX 2 (ab15258) mouse } & \multicolumn{3}{|c|}{6 - CDX 2 (ab15258) mouse + OCT4 (ab18976) rabbit } \\
\hline & \multicolumn{3}{|c|}{2 - CDX 2 (ab88129) rabbit } & \multicolumn{3}{|c|}{7 - CDX 2 (ab88129) rabbit + OCT4 (ab27985) goat } \\
\hline & \multicolumn{3}{|c|}{3 - OCT4 (ab27985) goat } & \multicolumn{3}{|c|}{8 - CDX 2 (ab15258) mouse + NANOG (500-P236) rabbit } \\
\hline & \multicolumn{3}{|c|}{4 - OCT4 (ab18976) rabbit } & \multicolumn{3}{|c|}{9 - CDX 2 (ab15258) mouse + H3K9me3 (07-442) rabbit } \\
\hline & \multicolumn{3}{|c|}{5 - NANOG (500-P236) rabbit } & \multicolumn{3}{|c|}{10 - OCT4 (ab27985) goat + NANOG (500-P236) rabbit } \\
\hline
\end{tabular}

\section{Results}

Gene expression patterns of key lineage specific marker genes during bovine preimplantation development In order to follow lineage specification during bovine preimplantation development we have first analysed the mRNA expression profile of selected pluripotency and lineage specific markers: OCT4, NANOG, FN-1, KLF4, $c-M Y C, R E X 1$, which are important for maintaining pluripotency in mouse and human and $C D X 2, K R T-18$ which are crucial for the establishment and the maintenance of TE as well as GATA6 involved in mouse PrE lineage segregation. Initially we have performed qualitative gene expression analyses to establish which genes were present in cattle morula and blastocyst stage embryos. Transcripts for all of the mentioned genes were detected in blastocysts and all except $c-M Y C$ and GATA6 were present in the morula stage embryos (Figure 1). Because for protein immunolocalisation we have chosen to concentrate on the 3 canonical lineage markers OCT4, NANOG and $\mathrm{CDX} 2$, we have also checked the presence of gene specific
mRNAs in 8-16 cell stage embryos, which in bovine is the time of major embryonic genome activation (Figure 1).

The expression patterns of key lineage specific marker genes in bovine blastocysts 9 dpi resembles the classical mouse model

In order to establish whether the investigated transcription factors were differentially expressed between bovine ICM and TE we have concentrated on the latest developmental stage that may be obtained in vitro under standard culture conditions - the hatched blastocyst stage ( $\mathrm{HBl}, 9 \mathrm{dpi})$. To separate the ICM from the TE, the embryos were microsurgically dissected. This method allowed collection of comparable samples as, unlike in rodents and higher primates, the bovine ICM is a clearly pronounced structure where polar TE quickly disappears after blastocyst expansion [42].

The results revealed significantly higher expression levels of OCT4, NANOG and FN-1 in bovine ICM as compared to TE (Figure 2). OCT4 mRNA level showed a 4-fold 


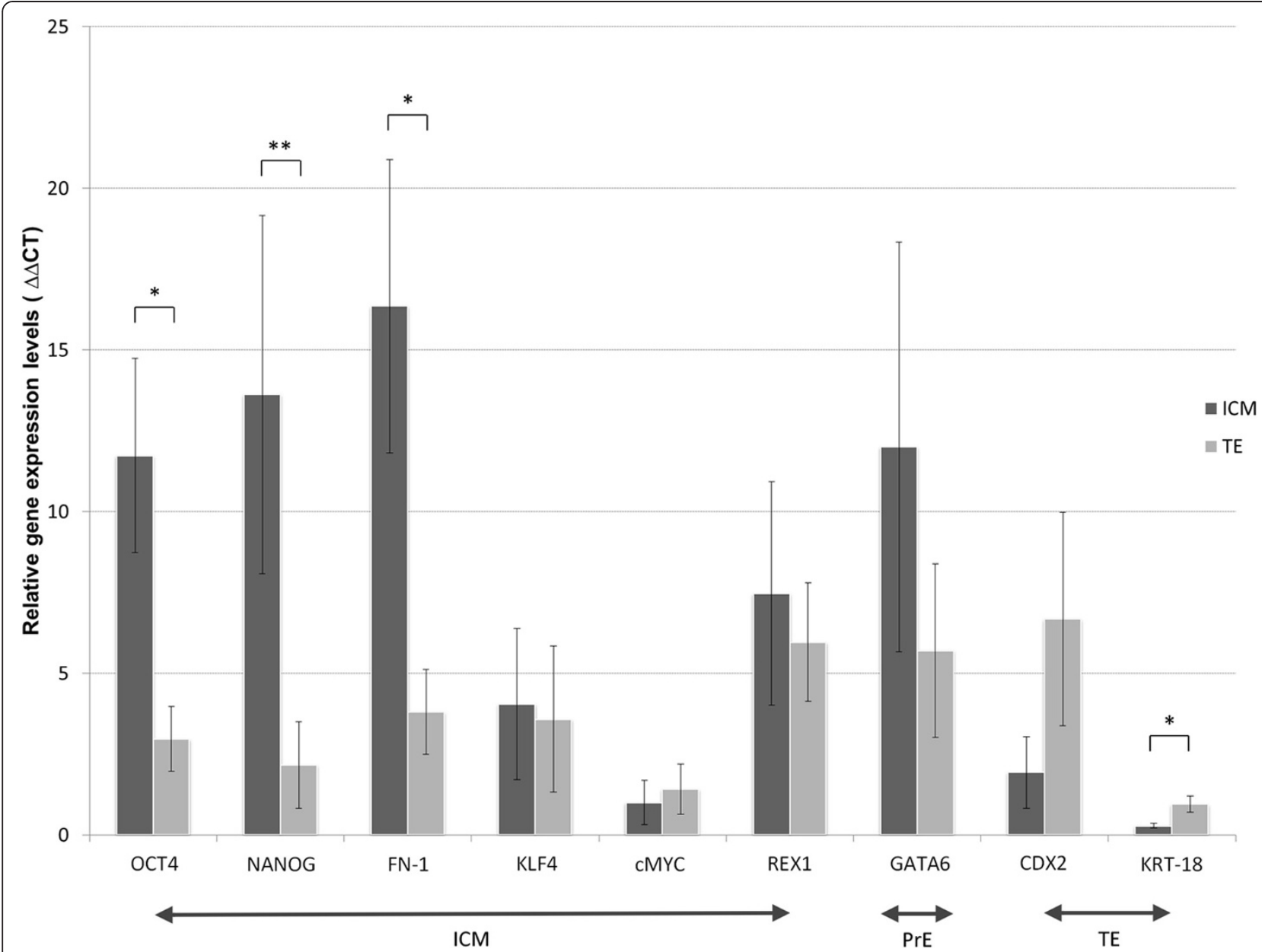

Figure 2 Comparison of gene expression levels between bovine ICM and TE. The graph represents relative expression levels of pluripotency and lineage specific genes in bovine ICM and TE. Asterisks denote significant differences in mRNA levels: ${ }^{*} P<0.05 ;{ }^{* *} P<0.01$. Error bars represent SEM.

up-regulation in the ICM $(\mathrm{P}=0.05)$ and NANOG and $F N-1$ gene expression levels were 6 -fold $(\mathrm{P}=0.002)$ and 4 -fold $(\mathrm{P}=0.015)$ higher in the ICM respectively. Out of 12 TE samples 6 did not express NANOG. The persistent expression of NANOG was possibly related to slight differences in the developmental timing of some of the blastocysts, as bovine blastocyst hatching is variable and takes place between $7.5 \mathrm{dpi}$ and $11 \mathrm{dpi}[43,44]$. In parallel, trophoblast related factors $C D X 2$ and KRT-18 also displayed lineage specific mRNA distribution pattern. In 9 out of 12 ICM samples $C D X 2$ transcripts were not detected. Overall $C D X 2$ expression level was 3-fold higher in bovine trophoblast versus the ICM. However the difference was not statistically significant $(P=0.071)$. The expression levels of KLF4, $c-M Y C$ and REX1 showed no specific differences between the ICM and the TE. GATA6 expression profile pointed towards its higher abundance in the ICM (2-fold), however a notable level of variability between the samples was observed $($ SEM $=6.33)$.
ICM specific transcription factors exhibit dynamic changes in subcellular localisation during bovine development

To complement the observations made from studies of ICM and TE transcription profiles we have immunolabelled the classical lineage and pluripotency marker proteins during bovine preimplantation period from the 5-cell stage until the hatched blastocyst stage (9dpi). Embryos were double labelled for various combinations of proteins: OCT4, NANOG and CDX2, which allowed examination of their mutual spatial correlation (Table 2). The control groups underwent the same staining protocol as the experimental group, with the exception of the primary antibody (the results are provided in the Additional file 1: Figure S1 section). The specificity of the CDX2 primary $\mathrm{AB}$ binding was verified with the use of blocking peptide (Figure 3). OCT4 binding was validated by performing double immunolabelling with both of the anti OCT4 antibodies used (Figure 4). The application of anti NANOG 


$$
\text { a }
$$

late morula

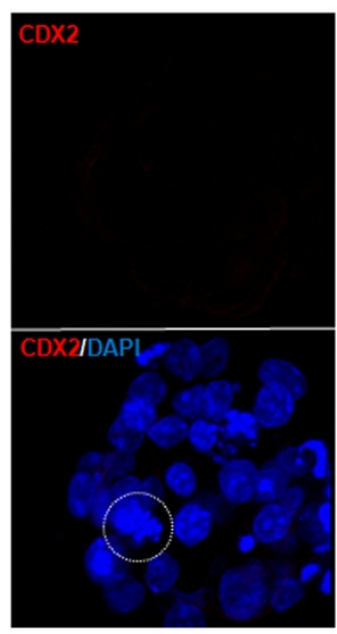

b

morula
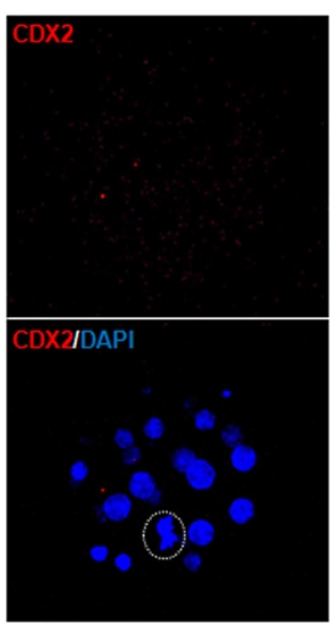

HBI, 9dpi
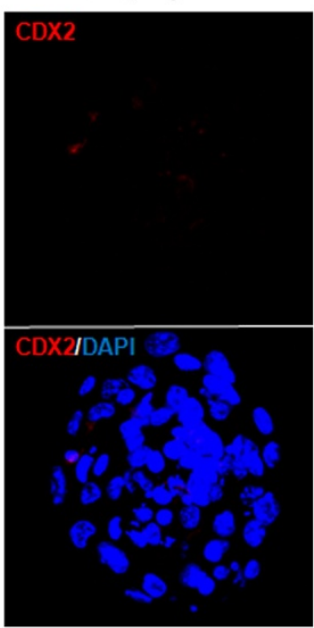

HBI, 9dpi
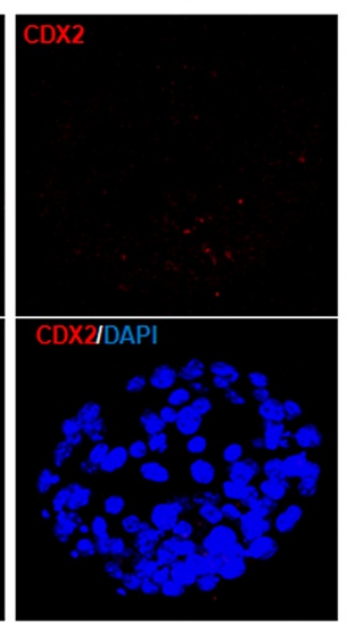

HBI, 9dpi

positive control

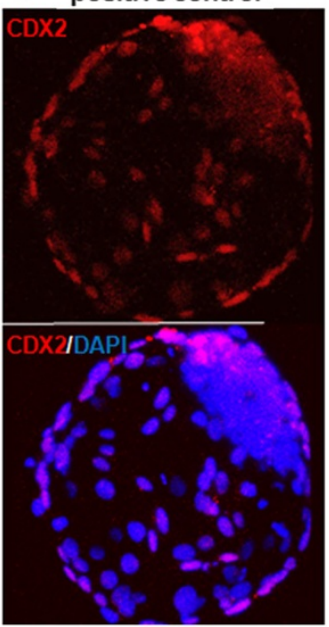

HBI, 9dpi positive control

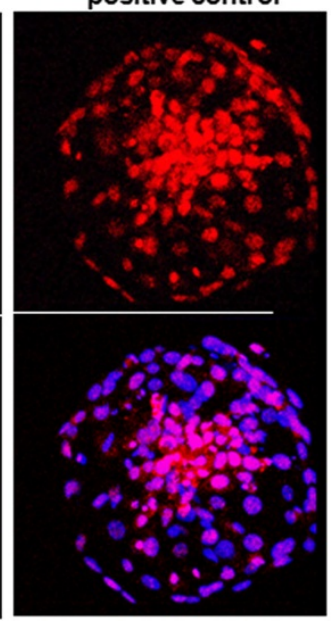

Figure 3 CDX2 immunolabelling controls. The binding specificity of the rabbit polyclonal anti CDX2 primary antibody (ab88129) (a) and mouse monoclonal anti CDX2 primary antibody (ab15258) (b) was verified with the use of blocking peptide (ab99158) prior to the antibody staining. The secondary antibodies used were goat anti-rabbit Rhodamine conjugated (sc-2091) in (a) and goat anti-mouse Rhodamine conjugated (sc-2092) in (b). Dashed circle marks the metaphase plate. DAPI labels chromatin.

(500-P236) and anti OCT4 (ab27985) antibody has been proven by Puy et al. [45] and He et al. [46].

\section{Inner cell mass lineage allocation}

OCT4 and NANOG protein distribution patterns were investigated during the crucial stages of bovine preimplantation development. NANOG was not detected in 5cell and 8-16 cell stage embryos, however as revealed by qualitative gene expression analysis, transcripts for both of these proteins were present (Figure 1). OCT4, the key transcription factor necessary to maintain the ICM, at the 5-cell stage occupied the apical surface of the blastomeres (a pattern identified in all of the analysed embryos). Around the 8-cell stage, the protein could be for the first time in development, located in the nuclei of all cells (Figure 5a). The situation changed at the morula stage, where both OCT4 and NANOG could be detected, however the distribution patterns were different. NANOG was localised in the cytoplasm of some cells, forming characteristic rings around the nucleus (Figure 5b, arrowheads). This data, combined with mRNA detection, suggests that NANOG protein appeared de novo at the morula stage as a product of the embryonic genome. Moreover NANOG positive cells seemed to be located in one area of the embryo (possibly the nascent ICM). At the same developmental stage OCT4 produced a nuclear signal in all cells. In early blastocysts (7dpi) OCT4 and NANOG proteins were found to be located both in the ICM and in the 

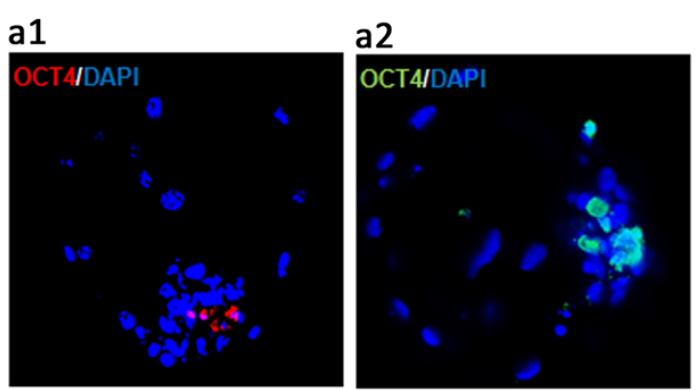

b
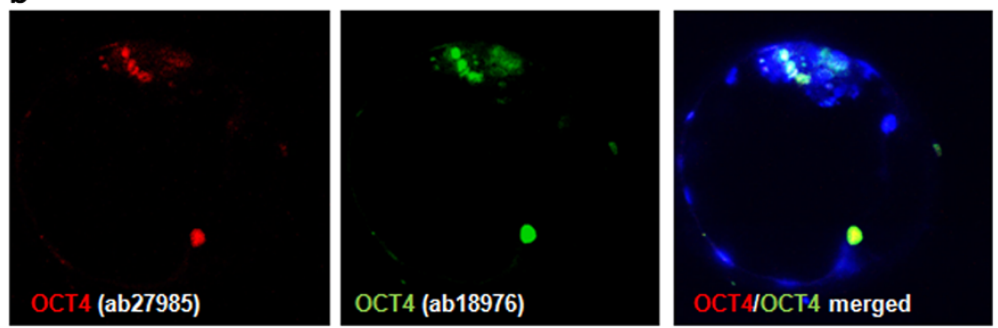

Figure 4 OCT4 immunolabelling controls. Control immunostaining with both of the anti OCT4 antibodies used in the experiment. (a1) presents HBL single labelled for OCT4 with goat polyclonal primary antibody (ab27985) detected with mouse anti-goat Rhodamine conjugated secondary antibody (sc-24900). (a2) presents single labelled HBI with rabbit polyclonal anti OCT4 antibody (ab18976) detected with goat anti-rabbit FITC conjugated secondary antibody (sc-2012). (b) indicates colocalisation of the OCT4 in HBI double-labelled with both of the anti OCT4 antibodies. The secondary antibodies used were mouse anti-goat Rhodamine conjugated (sc-2490) and donkey anti-rabbit FITC conjugated (sc-2090). DAPI labels chromatin.

surrounding TE cells, however their distribution patterns were different. In the ICM cells both NANOG and OCT4 displayed a nuclear localisation, however NANOG occupied the whole territory of the nucleus, whereas OCT4 showed more peripheral localisation, with "rings" at the nuclear periphery of the ICM cells (Figure 6a). In trophoblast cells, where OCT4/NANOG activity is redundant, proteins remained in the cytoplasm (Figure 6a, arrows). At 7/8dpi OCT4 positive blastomeres predominantly located in the ICM, however some positive signal was still detected within the TE cell population (Figure 6b). At the time of blastocyst hatching, still some residual immunolabelling could be observed in the TE layer, as indicated by a single cell co-expressing NANOG and OCT4 in Figure 6c. Following OCT4/CDX2 distribution patterns at the stages of blastocyst formation we have concluded that the process of ICM specific OCT4 allocation is gradual. Concomitant with blastocyst expansion at 8dpi OCT4 expressing cells become limited to the ICM, however single positive cells could be still identified in the TE of about $50 \%$ of the analysed embryos. After blastocyst hatching we have noted further evidence for lineage segregation. Both OCT4 and NANOG became exclusively ICM specific (Figure 6d). Within the group of cells expressing OCT4 and NANOG, we have identified cells expressing only NANOG (as indicated by red arrowheads in Figure 7b) and cells expressing both factors, with NANOG signal being predominantly nuclear and OCT4 showing some nuclear, some cytoplasmic localisation (white arrowheads in Figure $7 \mathrm{~b}$ ).

Trophoblast specific factor CDX2 changes its sub-nuclear localisation during bovine preimplantation development

To follow the process of bovine TE lineage specification, we have examined CDX2 distribution profile in 5-cell, 8-16 cell, morula and blastocyst stage embryos (7-9dpi). In 5-cell embryos CDX2 was located in the cytoplasm of all cells (Figure 8a) and unlike OCT4 showing a more pronounced distribution within the blastomeres and absence from the nucleus. At the subsequent stages of development CDX2 specifically allocated to the embryonic cell nuclei (Figure 8a). TE lineage specification becomes evident at more advanced developmental stages. At 7/8 dpi CDX2 segregation to the trophoblast cells could already be noted, however some signal was still detected within the ICM cells (Figure 8b) as indicated by a confocal section through an early blastocyst presented in Figure 6b.

A detailed analysis of the confocal images of the morula stage embryos indicated that the distribution pattern within the nucleus was not uniform. CDX2 formed a clear rim around the nuclear periphery and distinctive regions of high signal intensity were identified in both 8-16 cell and morula stage embryos (Figure 9a,b). These regions in some areas overlapped with DAPI (the fluorochrome used for DNA labelling: -4,6- diamidino-2-phenylindole). It was observed that DAPI preferably binds to the AT-rich regions 

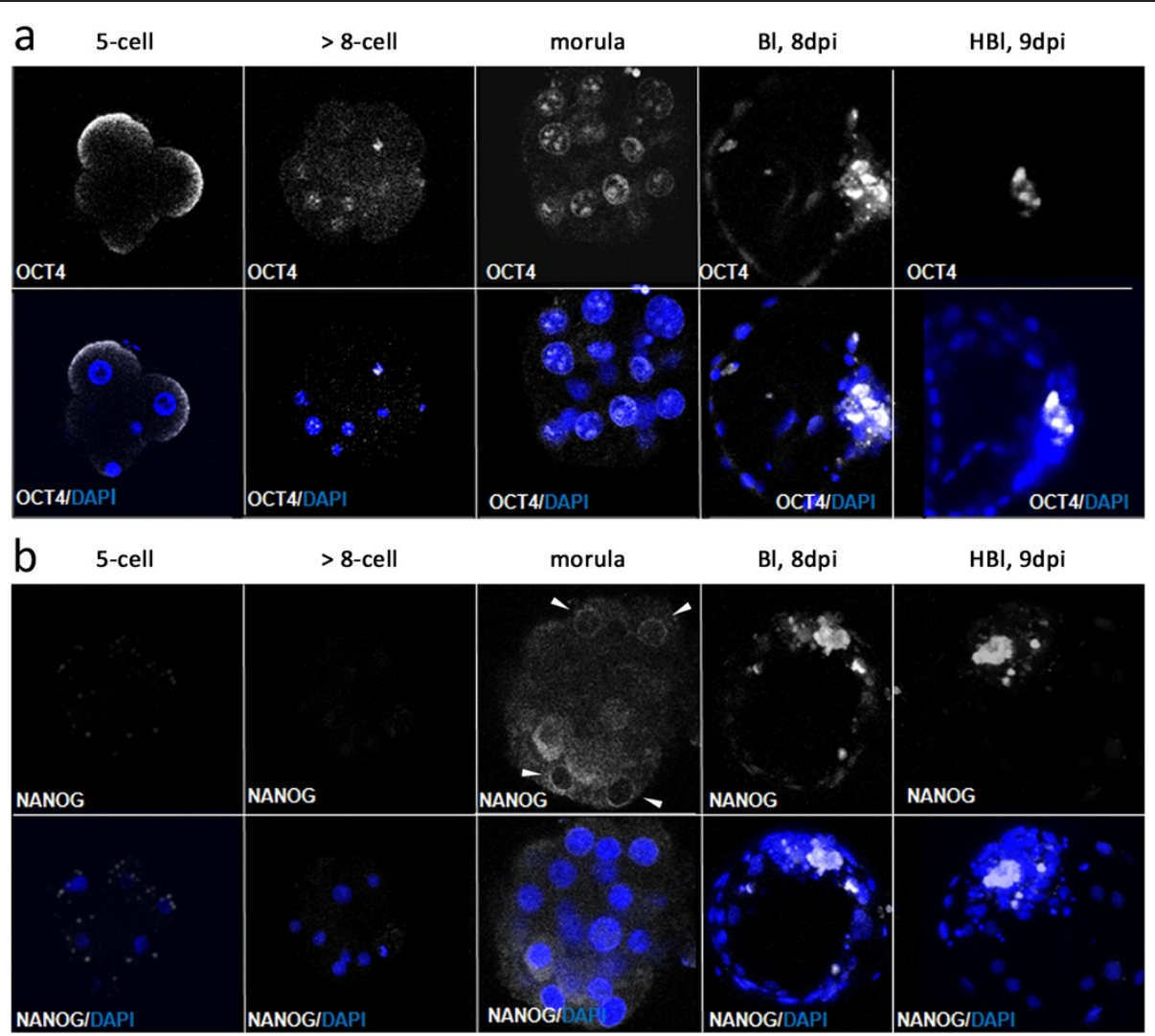

Figure 5 Distribution of OCT4 and NANOG in the early stages of bovine development. Immunofluorescent detection of OCT4 (a) and NANOG (b) followed through the early stages of bovine development. In 5-cell embryos OCT4 (a) localised at the apical surface of the blastomeres, and from the 8-16 cell stage weak signal was detected in cell nuclei and mostly absent in the cytoplasm. NANOG (b) immunostaining was for the first time detected at the morula stage exhibiting a specific cytoplasmic localisation with characteristic rings around the nuclear periphery (indicated by arrow heads). From the early stages of blastocyst formation OCT4 and NANOG signals were detected in the nuclei of the ICM cells. Confocal sections were taken every $3 \mu \mathrm{m}$. Chromatin was labelled with DAPI.

which are associated with heterochromatin [47]. Following that labelling property we have used an antibody directed against histone $\mathrm{H} 3$ lysine 9 tri-methylation (H3K9me3), which is highly correlated with predominantly transcriptionally silent constitutive heterochromatin regions. The results of double immunofluorescent staining revealed CDX2 and H3K9me3 colocalisation in the interphase nuclei of some cells. Most interestingly in double labelled 8-cell bovine embryos (4 out of 20) we have observed CDX2 localisation at specific regions of the metaphase chromosomes which colocalised with the H3K9me3 (Figure 9a). Also in 4 out of 9 metaphase plates that were altogether detected in 11 morula stage embryos, the specific chromosome coating was also visible (Figure 9b). On close examination we were also able to detect a CDX2 positive signal in a region occupied by a metaphase plate in a single TE cell of late blastocyst (Figure 9c). At this point we would like to stress that data interpretation must be done with much caution and that the possible CDX2 coating of metaphase chromosomes is presented as an observation.

\section{Discussion}

The existing evidence unequivocally indicates species specific differences in cell lineage allocation, as was highlighted by Janet Rossant: "A mouse is not a cow" [48]. However, in light of growing understanding of the signalling processes that control pre-implantation development, we believe that it is more important to ask whether we can identify the same/similar molecular mechanisms that govern cell fate decisions in mouse and in early bovine embryos. To address this question one has to be aware of the species specific differences in early development. The period of mouse preimplantation development is very short and takes 3.5 to 4.0 days. Bovine (and porcine) pre-attachment development is extended in time, as between the blastocyst formation and implantation there is about a 10-day time window during which the embryo undergoes further differentiation. Thus, it may be expected that the events leading to cellular specification and lineage formation in cattle may not be as rapid as in mice. Until now, with some exceptions the authors have concentrated mainly 

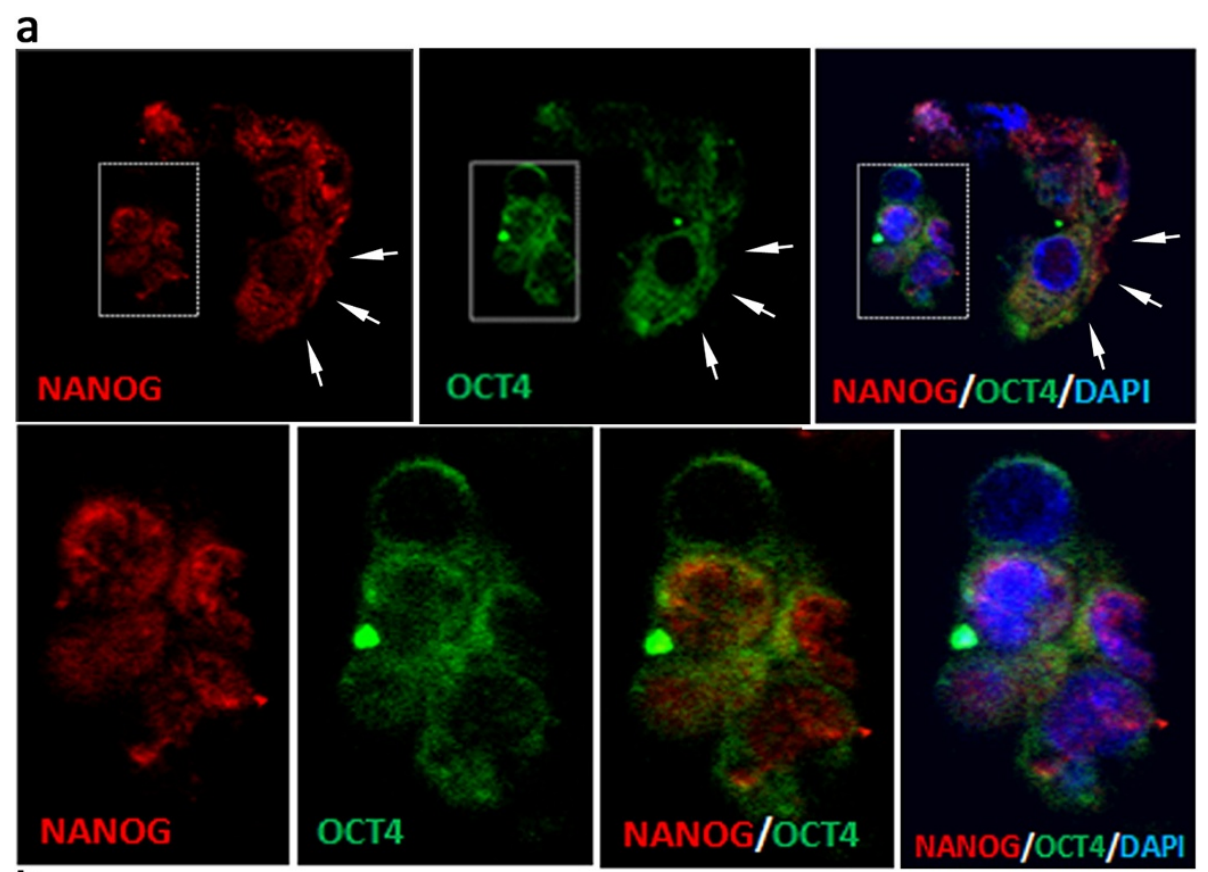

b
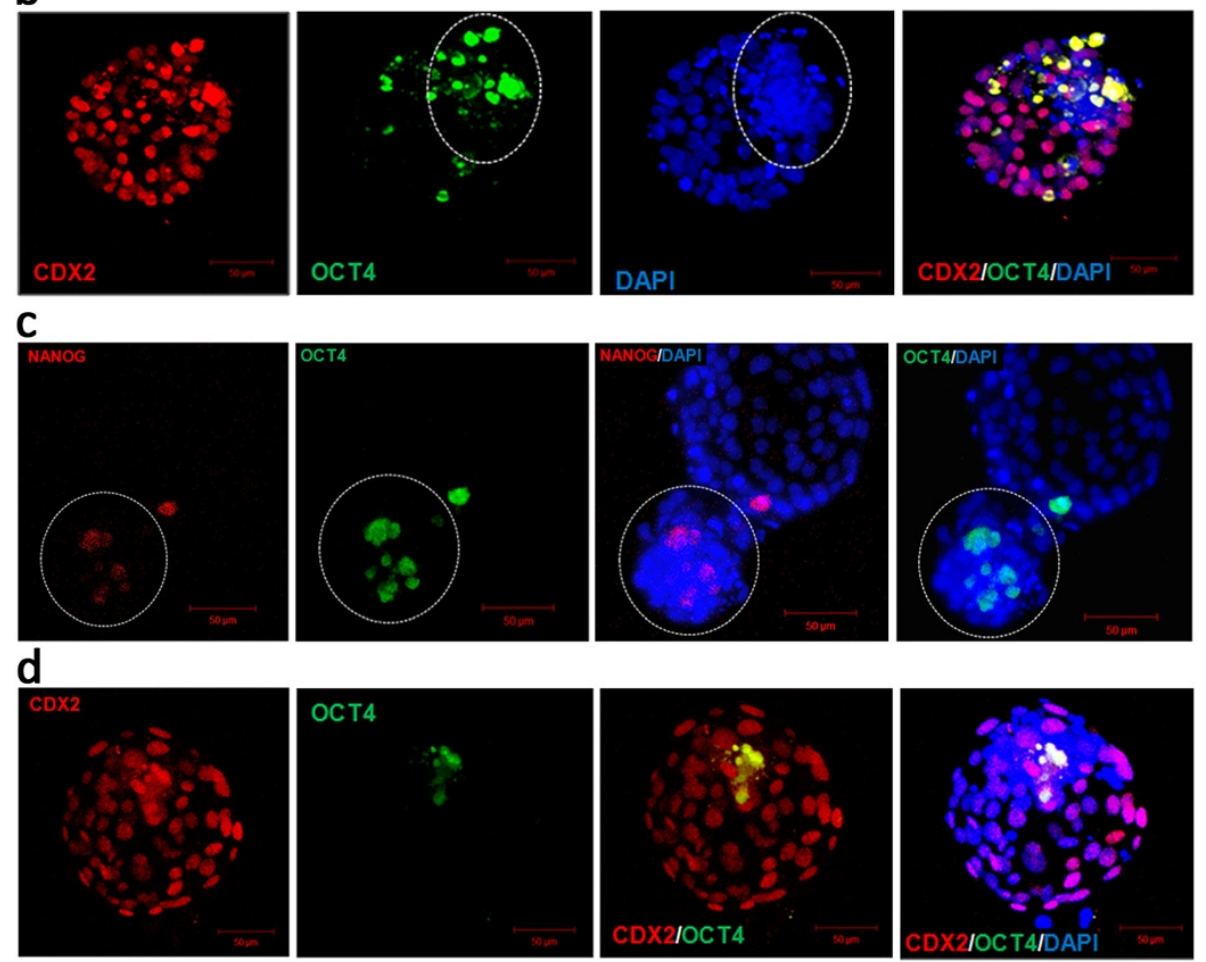

Figure 6 ICM lineage segregation during bovine blastocyst formation. (a) presents a single optical section through an ICM of bovine early blastocyst (7dpi) immunostained for NANOG and OCT4. The boxed areas are enlarged in the bottom row. NANOG shows nuclear and OCT4 sub-nuclear localisation in ICM White arrows indicate cytoplasmic localisation of NANOG and OCT4 in the trophoblast cells in the vicinity of the ICM. Confocal sections were taken every $2 \mu \mathrm{m}$ (b) shows a 3-D reconstruction of confocal images of an early blastocyst (7/8dpi) double labelled for CDX2 and OCT4. OCT4 was predominantly located in the ICM, but some signal was detected in the TE cells. Dashed circle marks the ICM. (c) is a 3-D compilation of optical sections taken through hatching blastocyst (8/9dpi) labelled for NANOG and OCT4. Dashed circle marks the ICM. (d) shows a 3-D reconstruction composed of 30 confocal sections (taken every $3 \mu \mathrm{m}$ ) through bovine hatched blastocyst (9dpi) double labelled for CDX2 and OCT4. At this stage OCT4 positive cells entirely segregate to the ICM. CDX2 becomes restricted to the trophoblast. DAPI marks chromatin. Confocal sections were taken every $3 \mu \mathrm{m}$. 


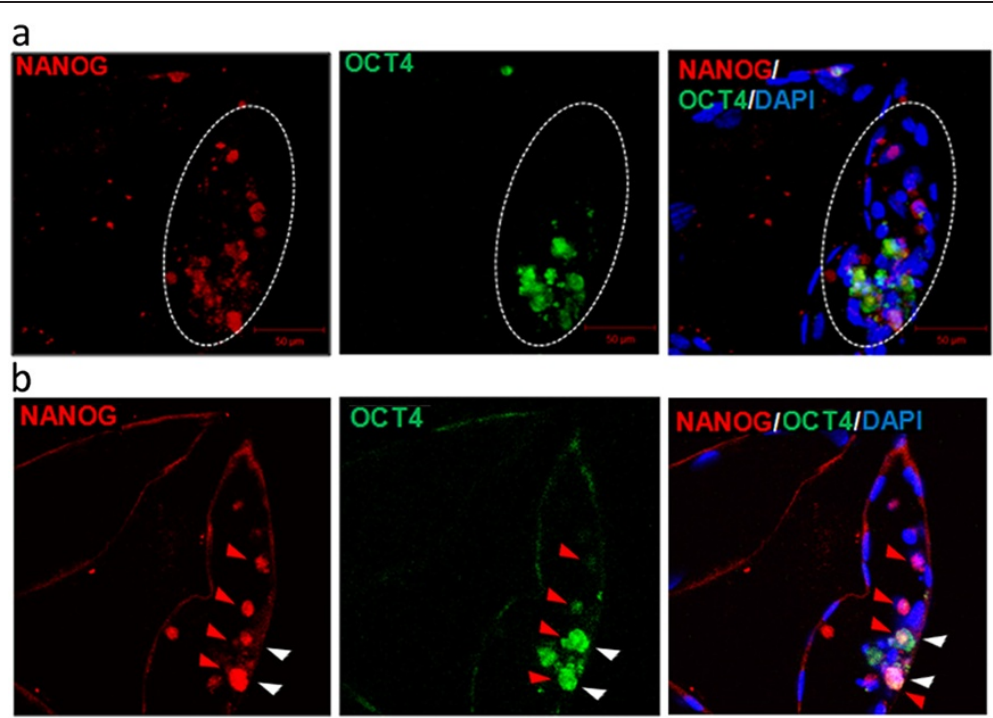

Figure 7 OCT4 and NANOG distribution pattern in bovine hatched blastocysts (9dpi). The top panel (a) of images shows a 3-D reconstruction of confocal sections taken through bovine HBL. Dashed line encircles the ICM. The bottom panel (b) represents a single optical section through the ICM of the same embryo. OCT4 and NANOG localise in the ICM, but a certain degree of signal segregation was observed. Cells indicated with red arrowheads express NANOG and cells indicated with white arrowheads co-express both proteins. DAPI marks chromatin. Confocal sections were taken every $3 \mu \mathrm{m}$.

on one developmental stage - the blastocyst at 8/9dpi. Three publications compared transcript abundance between bovine ICM and TE [49-51] however, the approach was mainly qualitative and did not include crucial developmental stages prior to blastocyst formation. Moreover, the existing data is often inconclusive as some authors showed no difference in OCT4 and NANOG protein distribution in bovine ICM and TE [52,53], whereas other $[54,55]$ showed partial OCT4 and NANOG expression in both embryonic lineages. On a contrary Kuijk et al.

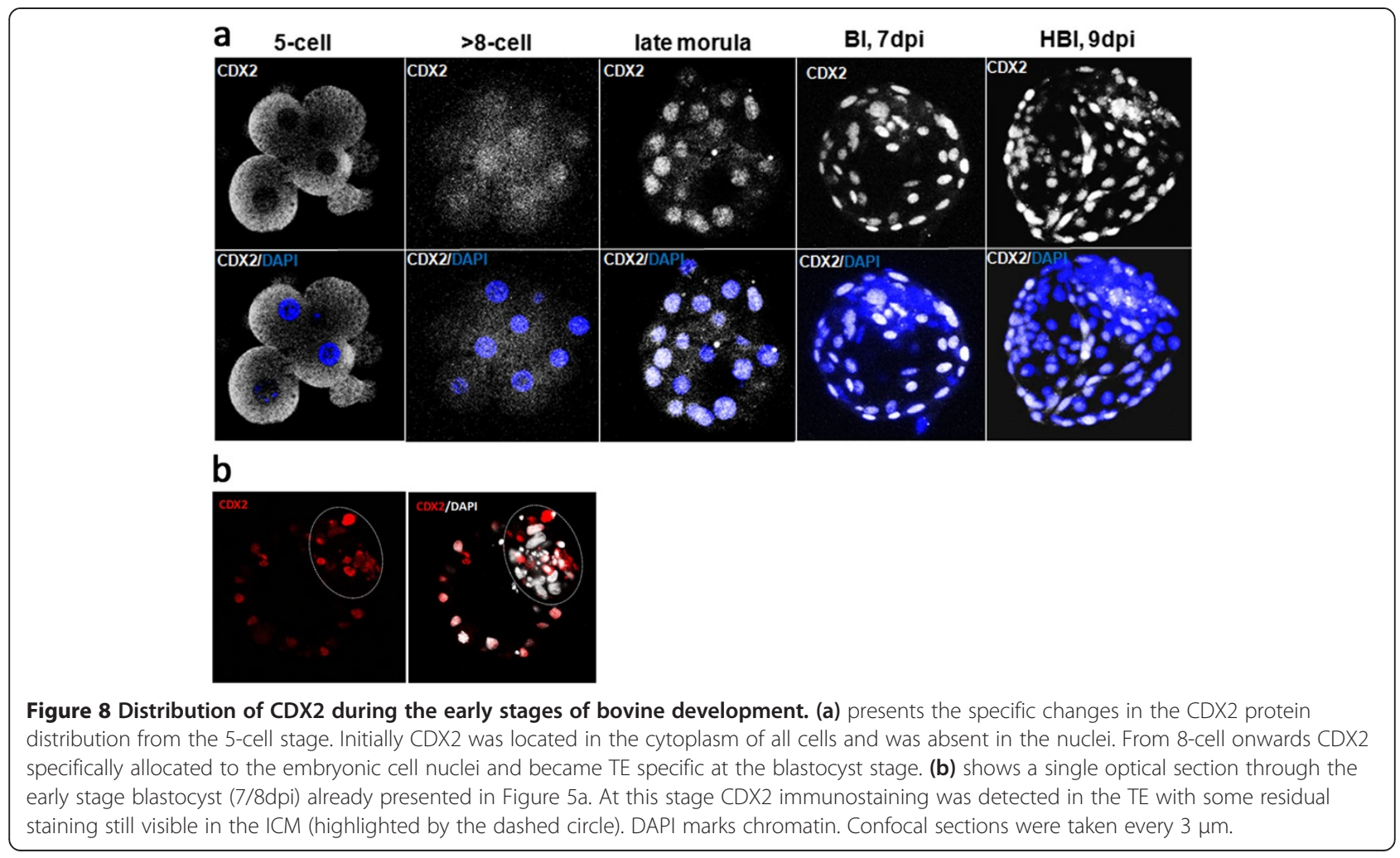



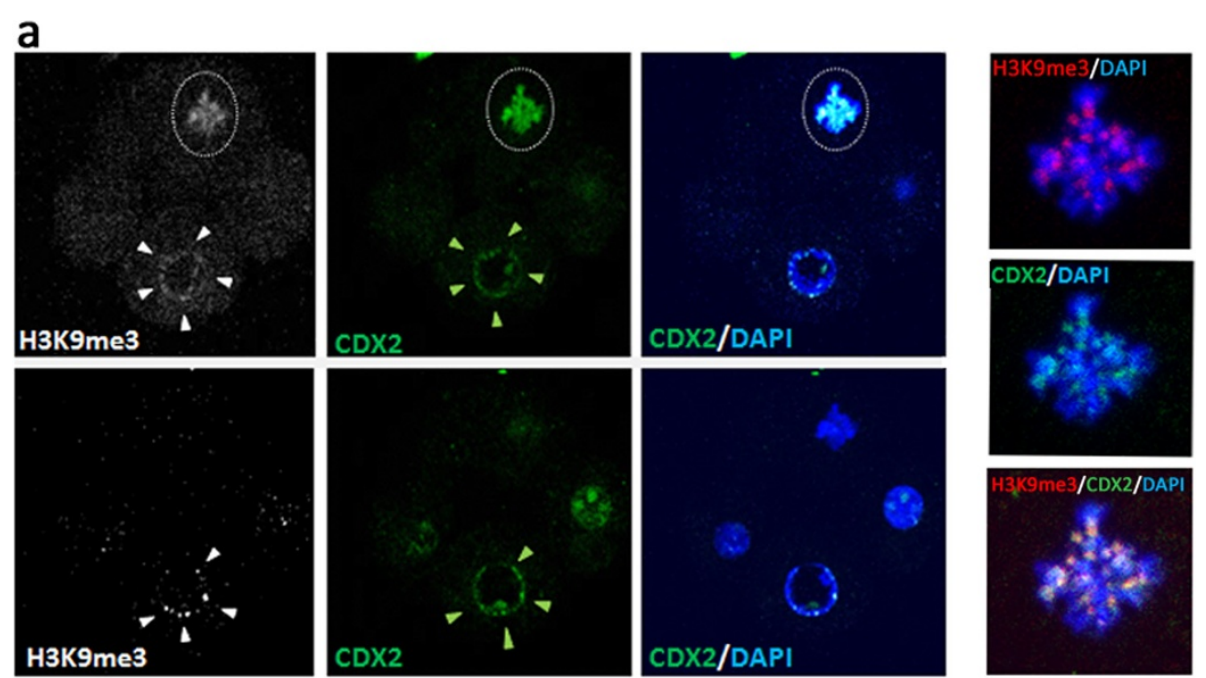

b
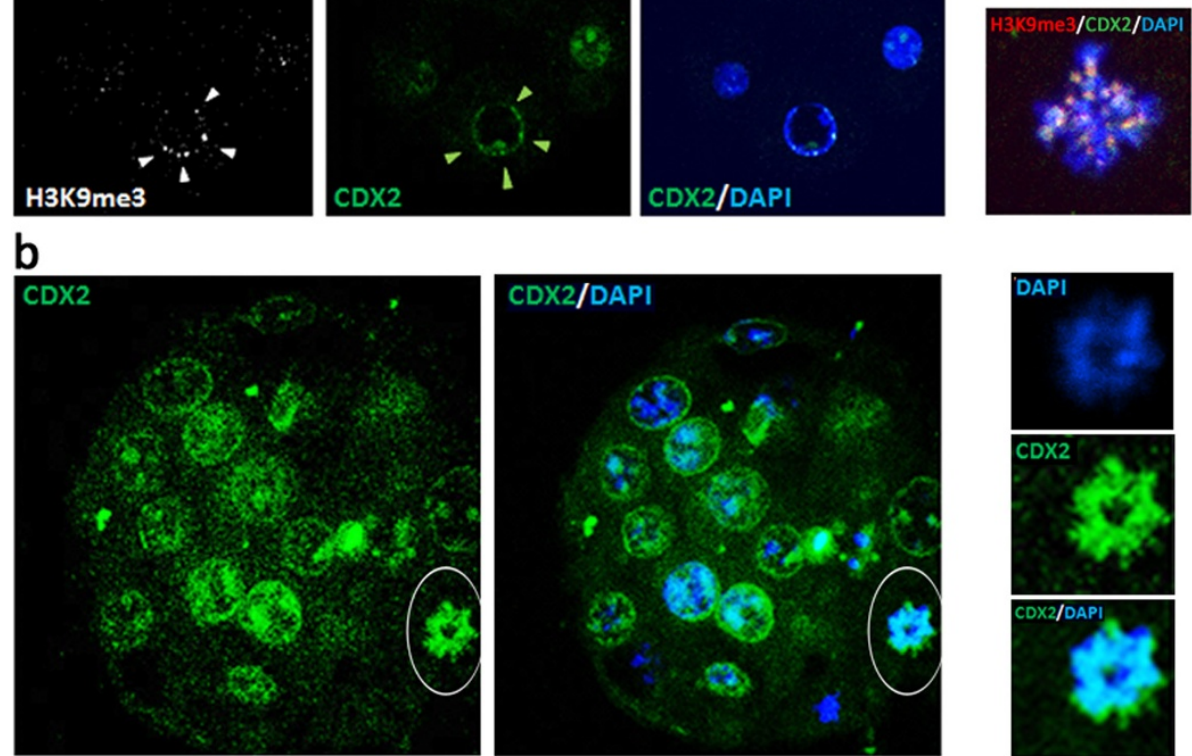

C
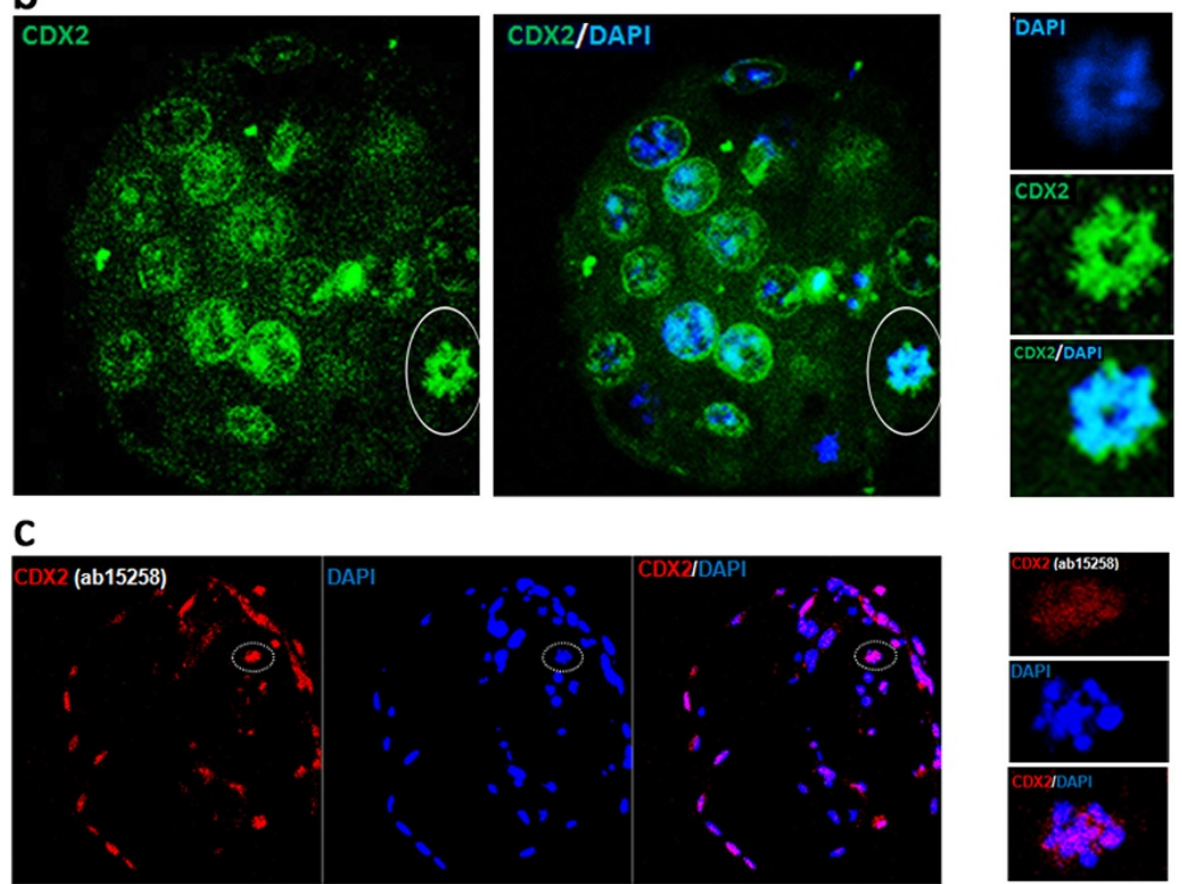

Figure 9 CDX2 displays nuclear localisation and labels metaphase chromosomes. (a) presents 2 consecutive optical sections through an early bovine embryo double labelled for CDX2 and for histone lysine methylation H3K9me3. White arrow heads point to a typical heterochromatin distribution pattern at the periphery of the interphase nucleus. Green arrow heads indicate CDX2 and H3K9me3 colocalisation. Dashed circle in (a) highlights the metaphase plate. CDX2 signal overlays the chromosomes and colocalises with condensed, transcriptionally silent chromatin as indicated by H3K9me3 immunostaining enlarged in the right panel. (b) presents an optical scan through middle of late morula embryo (beginnings of cavity formation may be visible in top section of the embryo). CDX2 displays nuclear localisation and also labels the metaphase chromosomes (marked by the dashed white circle, the area is enlarged in the boxed panel). (c) HBI (9dpi) immunostained for CDX2. Dashed white circle highlights the metaphase plate where, the encircled area is enlarged in the boxed panel where the CDX2 signal colocalisation with metaphase chromosomes is visible. DAPI marks chromatin. Confocal sections were taken every $3 \mu \mathrm{m}$.

$[56,57]$ localised NANOG solely in the ICM of bovine blastocysts. Therefore, the aim of our study was to resolve the doubts arising from the analysis of already published material on bovine lineage specification and to identify the time point at which bovine ICM/TE lineage segregation begins.
The first developmental stage investigated was the 5-cell stage which precedes the critical time in bovine development - the transition from maternal to embryonic control of development (MET) [58]. In the mouse MET is initiated at the 2-cell stage. In cattle this process is gradual and may be divided into three stages: (1) early gene activation 
in zygotes and 2-cell embryos [59]; (2) mid genome activation at 2-5 cell stage accompanied by de novo RNA synthesis [60-64] and (3) a major burst of gene activation at the $8-16$ cell stage. At the $8-16$ cell stage we have detected transcripts for the three canonical lineage markers: OCT4, NANOG and CDX2. The corresponding protein products were noted only for OCT4 and CDX2. Studies on in vitro derived bovine embryos revealed a sudden drop in the mRNA level around the 4-cell stage, reaching a minimal value at $8-16$ cells [65]. The results obtained here indicate that between the time of EGA and morula formation NANOG appear de novo as a product of the embryonic genome, as NANOG protein was detected from the morula stage onwards. In support of this assumption NANOG transcripts and protein were not detected in bovine germinal vesicle (GV) and in vitro matured oocytes [55]. Porcine embryos, which share similar morphological stages of preimplantation development with bovine embryos, display similar mRNA expression patterns for OCT4 and $C D X 2$ genes. After EGA, a sudden increase in the mRNA abundance was noted for bovine OCT4 and NANOG and for porcine OCT4 and CDX2 $[56,66]$. OCT4 transcript expression appears highly conserved between mouse and bovine blastocysts. In both species OCT4 transcription begins one to two cell cycles after zygotic genome activation and is followed by a sharp increase in the mRNA abundance subsequent to compaction. OCT4 mRNA was ubiquitously present in all cells of morula stage, however 7dpi (early bovine blastocyst stage) it become restricted to the ICM as indicated by in situ hybridisation [49].

Our studies indicate that early in development (5-cell stage) CDX2 and OCT4 proteins are both located in the cytoplasm of bovine blastomeres, however with slightly different distribution patterns. CDX2 was evenly distributed within the cytoplasm and absent in the nuclei. This is different from the expression pattern described in the mouse, where $\mathrm{Cdx} 2$ expression becomes detectable from 8-16 cell stage onwards with only nuclear localisation [15]. It indicates that CDX2 expression in cattle precedes the EGA and the stage at which a clear distinction between the inner and the outer cells becomes evident. OCT4 localised at the apical surface of the blastomeres. Asymmetric distribution of $C D X 2$ transcripts has been shown in the cytoplasm of early mouse embryos (4-8 cell) [66]. Cytoplasmic localisation implies synthesis and accumulation of proteins, thus prior to the EGA bovine embryos may be actively synthesising transcription factors required for lineage specification, what coincides with the gradual process of bovine genome activation. As indicated by our studies at the time of bovine genome activation CDX2 and OCT4 specifically allocate in the nuclei. Cell fate decisions are governed by active interactions between all of the core pluripotency factors, as cells co-express them until a certain threshold is achieved. In the mouse until the late blastocyst stage (3.5/4.0-dpi) CDX2, NANOG and OCT4 proteins exhibit salt and pepper distribution patterns ([41], rev [67]). In the bovine embryo this distribution has been observed, as early blastocysts (7dpi) contained on average 39.5\% double positive cells (NANOG and GATA6) [57]. At 8dpi only $6.7 \%$ of all NANOG positive cells within the ICM were also positive for GATA6 [57].

As development progresses bovine ICM/TE lineage specification becomes more evident. We have observed that in the early blastocyst (7dpi) at the time of cavitation and spatial separation of the two lineages OCT4 and NANOG occupy the nuclei of the ICM cells. In the neighbouring TE cells however, the proteins have colocalised in the cytoplasm and were absent from the nucleus. This may be the first indication at how functional differences correlate with the cell's position. In order to be active as transcription factors OCT4 and NANOG need to enter the nucleus, therefore at this stage the proteins may be subjected to an active transportation. OCT4 "rings" observed at the nuclear periphery of the ICM cells may be reflecting this activity. At mid blastocyst stage (8dpi) NANOG and OCT4 colocalised, which is in agreement with studies indicating mutual functional stimulation between these factors [68-71]. At the same developmental stage CDX2 segregation to the TE also became apparent, however some ICM cells still expressed both CDX2 and OCT4. Similarly as has been described in early mouse blastocysts [20], a residual CDX2 signal was detected in the ICM of bovine blastocysts, but in general the ICM was free of $\mathrm{CDX} 2$ immunostaining. In late blastocysts we observed OCT4 labelled cells only within the ICM. This has also been observed by Berg et al. [32], who noted measureable amounts of OCT4 in the TE of early bovine blastocysts (7dpi) and none by day 11 . The authors indicated that in cattle CDX2 does not repress OCT4 expression, since bovine OCT4 locus does not contain the cis-acting regulatory region necessary for extinguishing transcription in the TE. Nevertheless CDX2 is required for TE maintenance at later developmental stages. This is also true for other species: humans, primates, pigs, horses and rabbits [56,72-75]. Finally, in blastocysts 9dpi we have observed further cellular specification as we have noted cells expressing only NANOG and cells expressing both NANOG and OCT4. Our comparison of relative transcript abundance between bovine ICM and TE corresponds to the protein distribution patterns described here. At the mRNA level we have observed a lineage specific upregulation of OCT4, NANOG and FN1 in the ICM and KRT-18 in the TE. Notably, the majority of the ICM samples $(9 / 12)$ lacked the specific transcript for $C D X 2$. These results present a similar $C D X 2$ mRNA expression pattern as has been described for mouse, human and also recently primate embryos [73]. Consequently, within the set of the 
analysed TE samples 6 out of 12 did not express NANOG. Such segregation of key factors responsible for epiblast development may be a prerequisite to further differentiation processes that take place in the bovine embryo between the $\mathrm{HBl}$ stage and implantation (around 20dpi). In the mouse, the epiblast formation is defined by two segregation events that depend on the consecutive expression of Oct4 and Nanog. It is therefore plausible that our observations capture the time point at which these processes are initiated in bovine development and indicate that at the molecular level the machinery of cell lineage differentiation is active.

Interestingly factors considered as potential bovine blastocyst formation markers FN-1 and KRT-18 [76,77] also showed lineage specific differences. FN-1 is a glycoprotein component of the extracellular matrix involved in various processes related to early development such as fertilisation, gastrulation and implantation. We have noted $F N-1$ and KRT-18 transcripts already at the morula stage. FN-1 may be an important factor in the process of compaction and blastocyst formation, as its major biological functions are cell adhesion, cytoskeleton organisation and cell migration. Interactions between all of these processes are essential for early development and cell lineage segregation. Differentiative cell divisions at the morula stage create spatial grounds for the allocation of smaller inner cells to the ICM and larger polarised outer cells to the TE. KRT-18, a cytoskeletal protein, may be seen as a TE specific factor, since targeted deletion of KRT-18 in mouse embryos resulted in trophoblast fragility and early embryonic lethality [78]. We have detected a significant upregulation of KRT-18 gene in bovine TE as compared to the ICM, what makes it an interesting candidate for further investigations of bovine TE lineage formation. Other factors KLF4, c-MYC, REX1 and GATA6 did not exhibit lineage specific differences at the mRNA level. Studies showed that GATA6 mRNA was detected in both PrE and TE outgrowths of bovine blastocysts 8dpi [79]. Furthermore KLF4 and $c-M Y C$ may not be essential to maintain bovine ICM, since it was indicated that the expression of these two factors alongside OCT4 and SOX2, was not sufficient to induce pluripotency in bovine adult fibroblasts [80]. This may be explained by species specific differences between mouse and cattle as unlike in the mouse, bovine $\mathrm{TE}$ is formed from the cells surrounding the blastocyst cavity, not from the ones which cover the ICM [50]. Corresponding to our results Rex 1 mRNA was detected in mouse ICM and in polar trophoblast of $4.5 \mathrm{dpi}$ blastocyst. Later in mouse development Rex1 was found in trophoblast-derived tissues (ectoplacental cone and extraembryonic ectoderm) of the egg cylinder [81]. Thus Rex1 is regarded as the main factor enabling mouse ESC and epiblast stem cells (EpiSC) to be distinguished.

On a close examination of 8-cell, morula and blastocyst stage embryos we have made a very interesting observation, as in a small proportion of embryos (about 2\%) a positive signal for the CDX2 overlapped with the mitotic chromosomes. Moreover, the areas of higher CDX2 intensity in some regions colocalised with DNA labelling fluorochrome (DAPI), which to a certain degree may indicate the differences in chromatin compaction. Because DAPI preferably binds to the AT-rich heterochromatin regions [47] we have used an antibody directed against histone H3 lysine 9 tri-methylation (H3K9me3), which is believed to be associated with the formation of polyploid trophoblast giant cells from diploid trophoblast precursors [82] and together with H3K27 methylation in lysine is correlated with transcriptional repression [83]. In a study of the dynamics of constitutive heterochromatin in bovine nuclear transfer and in vitro produced embryos, H3K9me3 colocalised with heterochromatin protein CBX1 (HP1) in $95 \%$ of the nuclei and the signal was displayed in patches [84]. This expression pattern was similar to our observations. Double immunofluorescent labelling of 8-cell bovine embryos for $\mathrm{CDX} 2$ and $\mathrm{H} 3 \mathrm{~K} 9 \mathrm{me} 3$ revealed a possible colocalisation of these factors in the interphase nuclei and at the specific regions on the metaphase chromosomes. CDX2 and H3K9me3 colocalisation concurs with the above suggestions, especially since chromatin immunoprecipitation experiments have detected $\mathrm{H} 3 \mathrm{~K} 9 \mathrm{me} 3$ at numerous promoters in trophoblast tissues. Increased H3K9me3 levels were detected at $C d x 2$, Eomes and Esrrb promoter regions of ectoplacental cones as compared to extra embryonic endoderm. Thus H3K9me3 may be regarded as a repressive histone marker in early trophoblast development. At this stage data interpretation must be done with much caution, however the phenomenon of mitotic retention of cell fate determining transcription factors, as an epigenetic mechanism regulating gene expression has already been described [85]. At the time of EGA major transcriptional activation takes place. This process directly links chromatin changes, protein allocation and nuclear reorganisation. Mitotic remodelling of cellular and nuclear architecture includes dynamic redistribution of transcription factors (OCT4, ETS1, B-Myb, SP) and degradation of key regulatory proteins (such as cyclins) [86]. After mitosis, the structural and functional identity of cell's regulatory machinery must be re-established. Enzymatically and chemically sensitive sites on mitotic chromosomes mark active genes. It is therefore plausible that some regulatory complexes remain bound to the condensed chromatin for rapid reactivation after cell division. For example a hematopoietic cell fate determining factor Runx 2 remains associated with chromosomes during mitosis through sequence specific chromosome binding [85]. When transcription terminates at the time of chromosome condensation, Runx2 selectively occupies target gene promoters. This allows speculation on possible parallels with the observed CDX2 localisation pattern. There is an intriguing possibility that CDX2 
may play a role in the epigenetic regulation of embryonic cell fate through the process of mitotic retention. This is a new finding that is currently a subject of our detailed investigations.

\section{Conclusions}

We have observed that the protein distribution patterns in bovine blastocysts $8-9 \mathrm{dpi}$ mostly resemble the mouse model. The differences were noted at earlier developmental stages. In 5 cell embryos CDX2 and OCT4 proteins located in the cytoplasm of bovine blastomeres, but presented slightly different distribution patterns. CDX2 was evenly distributed within the cytoplasm and absent in the nuclei. OCT4 localised at the apical surface of the blastomeres. We have noted changes in sub-cellular and sub-nuclear distribution of pluripotency related factors during the subsequent stages of development. From 8-16 cell stage both proteins displayed a nuclear localisation, but from the morula stage the specific lineage segregation became visible as OCT4 became ICM specific and CDX2 located in the TE layer. NANOG was initially detected in the cytoplasm of certain cells of the morula stage embryos and became ICM specific at $8 \mathrm{dpi}$. Finally it may be speculated that CDX2 possibly occupies transcriptionally silent regions of the early bovine nuclei as it was found to colocalise with about $2 \%$ of the observed metaphase plates.

\section{Additional file}

Additional file 1: Figure S1. Control staining of bovine blastocysts subjected to the same immunolabelling protocol as the experimental group, with the exception of primary antibodies. Scale bar $=50 \mu \mathrm{m}$.

\section{Competing interests}

The authors declare no competing interests.

\section{Authors' contributions}

ZEM is the grant holder, designed and performed the research, analysed the data and wrote the manuscript; JS performed immunofluorescent staining experiments and was involved in confocal analyses; $\mathrm{KH}$ and EW were involved in IVP experiments; PP helped with confocal imaging; NR and DL contributed to data analysis; BP was involved in research development and participated in manuscript preparation. All authors read and approved the final manuscript.

\section{Acknowledgements \\ The authors would like to thank Prof. P. Tryjanowski (Institute of Zoology, Poznan University of Life Sciences, Poland) for his help with the statistical analysis; MSc. M. Orsztynowicz for his involvement in bovine in vitro embryo production; Dr F. Santos (The Babraham Institute, Cambridge) for her advice and helpful suggestions; Prof. M. Switonski (Head of the Department of Genetics and Animal Breeding, Poznan University of Life Sciences, Poland) for his comments on the manuscript; The Department of Animal Physiology and Biochemistry, Poznan University of Life Sciences, Poland for making accessible their Confocal Microscope Facility. Berenila Plusa is supported by a Manchester University fellowship. The study was financed by The Foundation For Polish Science (FNP), Grant Number: $\mathrm{HOM} / 2009 / 6 \mathrm{~B}$}

\section{Grant sponsor}

Foundation For Polish Science (FNP), Grant Number: HOM/2009/6B.

\section{Author details}

${ }^{1}$ Department of Genetics and Animal Breeding, Poznan University of Life Sciences, Wolynska 33, Poznan 60-673, Poland. 'Department of Reproduction and Stem Cells, Institute of Human Genetics, Polish Academy of Sciences, Poznan, Poland. ${ }^{3}$ Faculty of Life Sciences, The University of Manchester, Manchester, UK.

Received: 17 December 2012 Accepted: 7 August 2013

Published: 13 August 2013

\section{References}

1. Adjaye J, Herwig R, Brink TC, Herrmann D, Greber B, Sudheer S, Groth D, Carnwath JW, Lehrach H, Niemann H: Conserved molecular portraits of bovine and human blastocysts as a consequence of the transition from maternal to embryonic control of gene expression. Physiol Genomics 2007, 31:315-327.

2. Krischer RL: Utility of animal models for human embryo culture development: domestic species. Embryo cult: Methods Protoc, Methods Mol Bio 2012, 912:27-37.

3. Oron $E$, Ivanova $\mathrm{N}$ : Cell fate regulation in early mammalian development. Phys Biol 2012, 9:1-17.

4. Alexopoulos NI, Vajta G, Lewis I, Rogers P, Cann L, Callesen H, TvedenNyborg P, Trounson A: Immunohistochemical and ultrastructural characterization of the initial post-hatching development of bovine embryos. Reproduction 2003, 125:607-623.

5. Aghion J, Gueth-Hallonet C, Antony C, Gros D, Maro B: Cell adhesion and gap junction formation in the early mouse embryo are induced prematurely by 6-DMAP in the absence of E cadherin phosphorylation. J Cell Sci 1994, 107:1369-1379.

6. Pauken CM, Capco DG: The expression and stage-specific localization of protein kinase $\mathrm{C}$ isotypes during mouse preimplantation development. Dev Biol 2000, 223:411-412.

7. Plusa B, Frankenberg S, Chalmers A, Hadjantonakis AK, Moore CA, Papalopulu N, Papaioannou VE, Glover DM, Zernicka-Goetz M: Downregulation of Par3 and aPKC function directs cells towards the ICM in the preimplantation mouse embryo. J Cell Sci 2005, 118:505-515.

8. Louvet S, Aghion J, Santa-Maria A, Mangeat P, Maro B: Ezrin becomes restricted to outer cells following asymmetrical division in the preimplantation mouse embryo. Dev Biol 1996, 177:568-569.

9. Johnson $\mathrm{MH}$, Ziomek CA: Induction of polarity in mouse 8-cell blastomeres: specificity, geometry, and stability. J Cell Biol 1981, 91:303-308.

10. Johnson MH, Ziomek CA: The foundation of two distinct cell lineages within the mouse morula. Cell 1981, 24:71-80.

11. Yagi R, Kohn MJ, Karavanova I, Kaneko KJ, Vullhorst D, DePamphilis ML, Buonanno A: Transcription factor TEAD4 specifies the trophectoderm lineage at the beginning of mammalian development. Development 2007, 134:3827-3836.

12. Nishioka N, Inoue K-I, Adachi K, Kiyonari H, Ota M, Ralston A, Yabuda N, Hirahara S, Stephenson RO, Ogonuki N: The Hippo signalling pathway components Lats and Yap pattern Tead4 activity to distinguish mouse trophectoderm from inner cells. Devel Cell 2009, 16:398-410.

13. Home P, Ray S, Dutta D, Bronshteyn I, Larson M, Paul S: GATA3 is selectively expressed in the trophectoderm of peri-implantation embryo and directly regulates Cdx2 gene expression. J Biol Chem 2009, 284:28729-28737.

14. Ralston A, Cox BJ, Nishioka N, Sasaki H, Chea E, Rugg-Gunn P, Guo G, Robson P, Draper JS, Rossant J: Gata3 regulates trophoblast development downstream of Tead4 and in parallel to Cdx2. Development 2010, 137:395-403.

15. Ralston A, Rossant J: Cdx2 acts downstream of cell polarization to cellautonomously promote trophectoderm fate in the early mouse embryo. Dev Biol 2008, 313:614-629.

16. Strumpf D, Mao CA, Yamanaka Y, Ralston A, Chawengsaksophak K, Beck F, Rossant J: Cdx2 is required for correct cell fate specification and differentiation of trophectoderm in the mouse blastocyst. Development 2005, 132:2093-2102.

17. Russ AP, Wattler S, Colledge WH, Aparicio SA, Carlton MB, Pearce JJ, Barton SC, Surani MA, Ryan K, Nehls MC, Wilson V, Evans MJ: Eomesodermin is required for mouse trophoblast development and mesoderm formation. Nature 2000, 404:95-99. 
18. Ng RK, Dean W, Dawson C, Lucifero D, Madeja Z, Reik W, Hemberger M: Epigenetic restriction of embryonic cell lineage fate by methylation of Elf5. Nat Cell Biol 2008, 10:1280-1290

19. Sasaki $\mathrm{H}$ : Mechanisms of trophectoderm fate specification in preimplantation mouse development. Dev Growth Diffr 2010, 52:263-273.

20. Dietrich JE, Hiiragi T: Stochastic patterning in the mouse pre-implantation embryo. Development 2007, 134:4219-4231.

21. Kondratiuk I, Bazydlo K, Maleszewski M, Szczepanska K: Delay of polarization event increases the number of $\mathrm{Cd}$ x2-positive blastomeres in mouse embryo. Dev Biol 2012, 368:54-62.

22. Niwa H, Toyooka Y, Shimosato D, Strumpf D, Takahashi K, Yagi R, Rossant J: Interaction between Oct3/4 and Cdx2 determines trophectoderm differentiation. Cell 2005, 123:917-929.

23. Nishiyama A, Xin L, Sharov AA, Thomas M, Mowrer G, Meyers E, Piao Y, Mehta S, Yee S, Nakatake Y, Stagg C, Sharova L, Correa-Cerro LS, Bassey U, Hoang H, Kim E, Tapnio R, Qian Y, Dudekula D, Zalzman M, Li M, Falco G, Yang HT, Lee SL, Monti M, Stanghellini I, Islam MN, Nagaraja R, Goldberg I, Wang W, et al: Uncovering early response of gene regulatory networks in ESCs by systematic induction of transcription factors. Cell Stem Cell 2009, 5:420-433

24. Nichols J, Zevnik B, Anastassiadis K, Niwa H, Klewe-Nebenius D, Chambers I Scholer $\mathrm{H}$, Smith A: Formation of pluripotent stem cells in the mammalian embryo depends on the POU transcription factor Oct4. Cell 1998, 95:379-391.

25. Mitsui K, Tokuzawa Y, Itoh H, Segawa K, Murakami M, Takahashi K, Maruyama M, Maeda M, Yamanaka S: The homeoprotein Nanog is required for maintenance of pluripotency in mouse epiblast and ES cells. Cell 2003, 113:631-642

26. Elling U, Klasen C, Eisenberger T, Anlag K, Treier M: Murine inner cell massderived lineages depend on Sall4 function. Proc Natl Acad Sci U S A 2006, 103:16319-16324.

27. Avilion AA, Nicolis SK, Pevny LH, Perez L, Vivian N, Lovell-Badge R: Multipotent cell lineages in early mouse development depend on SOX2 function. Genes Dev 2003, 17:126-140

28. Roper S, Hemberger M: Defining pathways that enforce cell lineage specification in early development and stem cells. Cell Cycle 2009, 8:1515-1525.

29. Masui S, Nakatake Y, Toyooka Y, Shimosato D, Yagi R, Takahashi K, Okochi H, Okuda A, Matoba R, Sharov AA, Ko MS, Niwa H: Pluripotency governed by Sox2 via regulation of Oct3/4 expression in mouse embryonic stem cells. Nat Cell Biol 2007, 9:625-635.

30. Chambers I, Colby D, Robertson M, Nichols J, Lee S, Tweedie S, Smith A: Functional expression cloning of Nanog, a pluripotency sustaining factor in embryonic stem cells. Cell 2003, 113:643-655.

31. Chen L, Yabuuchi A, Eminli S, Takeuchi A, Lu CW, Hochedlinger K, Daley GQ: Cross-regulation of the Nanog and Cdx2 promoters. Cell Res 2009, 19:1052-1061.

32. Berg DK, Smith CS, Pearton DJ, Wells DN, Broadhurst R, Donnison M, Pfeffer PL: Trophectoderm lineage determination in cattle. Cell 2011, 20:244-255.

33. De-Loos F, Van-Vliet C, Van-Maurik P, Kruip TA: Morphology of immature bovine oocytes. Gamete Res 1989, 24:197-204.

34. Stinshoff $\mathrm{H}$, Wilkening $\mathrm{S}$, Hanstedt A, Brüning $\mathrm{K}$, Wrenzycki C: Cryopreservation affects the quality of in vitro produced bovine embryos at the molecular level. Theriogenology 2011, 76:1433-1441.

35. Parrish JJ, Susko-Parrish JL, Graham JK: In vitro capacitation of bovine spermatozoa: role of intracellular calcium. Theriogenology 1998, 51:461-472

36. Holm P, Booth PJ, Schmidt MH, Greve T, Callesen H: High bovine blastocyst development in a static in vitro production system using SOFaa medium supplemented with sodium citrate and myo-inositol with or without serum-proteins. Theriogenology 1999, 52:683-700.

37. Livak KJ, Schmittgen TD: Analysis of relative gene expression data using real-time quantitative PCR and the 2(-Delta Delta C(T)). Methods 2001, 25:402-408.

38. Schmittgen TD, Livak KJ: Analyzing real-time PCR data by the comparative C(T) method. Nat Protoc 2008, 3:1101-1108.

39. Rekik W, Dufort I, Sirard MA: Analysis of the gene expression pattern of bovine blastocysts at three stages of development. Mol Reprod Dev 2011 78:226-240

40. Madeja Z, Yadi H, Apps R, Boulenouar S, Roper SJ, Gardner L, Moffett A, Colucci F, Hemberger M: Paternal MHC expression on mouse trophoblast affects uterine vascularization and fetal growth. Proc Natl Acad Sci U S A 2011, 108:4012-4017.
41. Plusa B, Piliszek A, Frankanberg S, Artus J, Hadjantonakis AK: Distinct sequential cell behaviours direct primitive endoderm formation in the mouse blastocyst. Development 2008, 135:3081-3091.

42. Viebahn C: The anterior margin of the mammalian gastrula: comparative and phylogenetic aspects of its role in axis formation and head induction. Curr Top Dev Biol 1999, 46:63-103.

43. Vejlsted M, Du Y, Vajta G, Maddox-Hyttel P: Post-hatching development of the porcine and bovine embryo-defining criteria for expected development in vivo and in vitro. Theriogenology 2006, 65:153-165.

44. Peippo J, Machaty Z, Peter A: Terminologies for the pre-attachment bovine embryo. Theriogenology 2011, 76:1373-1379.

45. Du-Puy L, Lopes SM, Haagsman HP, Roelen BA: Analysis of co-expression of OCT4, NANOG and SOX2 in pluripotent cells of the porcine embryo, in vivo and in vitro. Theriogenology 2011, 75:513-526.

46. He S, Pant D, Schiffmacher A, Bischoff S, Melican D, Gavin W, Keefer C: Developmental expression of pluripotency determining factors in caprine embryos: novel pattern of NANOG protein localization in the nucleolus. Mol Reprod Dev 2006, 73:1512-1522.

47. Zink D, Sadoni N, Ernst SE: Visualizing chromatin and chromosomes in living cells. Methods 2003, 29:42-50.

48. Rossant J: A mouse is not a cow. Nature 2011, 471:457-458.

49. Kurosaka S, Eckardt S, McLaughlin KJ: Pluripotent lineage definition in bovine embryos by Oct4 transcript localization. Biol Reprod 2004, 71:1578-1582

50. Degrelle SA, Campion E, Cabau C, Piumi F, Reinaud P, Richard C, Renard JP, Hue I: Molecular evidence for a critical period in mural trophoblast development in bovine blastocysts. Dev Biol 2005, 288:448-460

51. Maruotti J, Muñoz M, Degrelle SA, Gómez E, Louet C, Monforte CD, DeLongchamp PH, Brochard V, Hue I, Caamaño JN, Jouneau A: Efficient derivation of bovine embryonic stem cells needs more than active core pluripotency factors. Mol Reprod Dev 2012, 79:461-477.

52. Cao S, Wang F, Chen Z, Liu Z, Mei C, Wu H, Huang J, Li C, Zhou L, Liu L: Isolation and culture of primary bovine embryonic stem cell colonies by a novel method. J Exp Zool A Ecol Genet Physiol 2009, 311:368-376.

53. Wang L, Duan E, Sung LY, Jeong BS, Yang X, Tian XC: Generation and characterization of pluripotent stem cells from cloned bovine embryos. Biol Reprod 2005, 73:149-155.

54. Khan DR, Dubé D, Gall L, Peynot N, Ruffini S, Laffont L, Le-Bourhis D, Degrelle $S$, Jouneau A, Duranthon V: Expression of pluripotency master regulators during two key developmental transitions: EGA and early lineage specification in the bovine embryo. PLoS One 2012, 7:1-11.

55. Pant $D$, Keefer $C L$ : Expression of pluripotency-related genes during bovine inner cell mass explant culture. Cloning Stem Cells 2009, 11:355-365.

56. Kuijk EW, Du-Puy L, Van-Tol HT, Oei CH, Haagsman HP, Colenbrander B, Roelen BA: Differences in early lineage segregation between mammals. Dev Dyn 2008, 237:918-927.

57. Kuijk EW, Van-Tol LTA, Van De-Velde H, Wobbolts R, Welling M, Geijsen N, Roelen $\mathrm{B}$ : The roles of FGF and MAP kinase signalling in the segregation of the epiblast and hypoblast cell lineages in bovine and human embryos. Development 2012, 139:871-882

58. Telford NA, Watson AJ, Schultz GA: Transition from maternal to embryonic control in early mammalian development: a comparison of several species. Mol Reprod Dev 1990, 26:90-100.

59. Mamo S, Rizos D, Lonergan P: Transcriptomic changes in the bovine conceptus between the blastocyst stage and initiation of implantation. Anim Reprod Sci 2012, 134:56-63.

60. Memili E, First NL: Control of gene expression at the onset of bovine embryonic development. Biol Reprod 1999, 61:1198-1207.

61. Viuff D, Avery B, Greve T, King WA, Hyttel P: Transcriptional activity in in vitro produced bovine two- and four-cell embryos. Mol Reprod Dev 1996, 43:171-179.

62. Hyttel P, Viuff D, Avery B, Laurincik J, Greve T: Transcription and cell cycledependent development of intranuclear bodies and granules in two-cell bovine embryos. J Reprod Fertil 1996, 108:263-270.

63. Memili E, First NL: Developmental changes in RNA polymerase II in bovine oocytes, early embryos, and effect of alpha-amanitin on embryo development. Mol Reprod Dev 1998, 51:381-389. 
64. Natale DR, Kidder GM, Westhusin ME, Watson AJ: Assessment of differential display-RT-PCR of mRNA transcript transitions and alphaamanitin sensitivity during bovine preattachment development. $\mathrm{Mol}$ Reprod Dev 2000, 55:152-163.

65. Vigneault C, McGraw S, Massicotte L, Sirard MC: Transcription factor expression patterns in bovine in vitro-derived embryos prior to maternal-zygotic transition. Biol Reprod 2004, 70:1701-1709.

66. Skamagki M, Wicher KB, Jedrusik A, Ganguly S, Zernicka-Goetz M: Asymmetric localization of $\mathrm{Cd} \times 2$ mRNA during the first cell-fate decision in early mouse development. Cell Rep 2013, 3:442-457.

67. Saiz N, Plusa B: Early cell fate decisions in the mouse embryo. Reproduction 2013, 145:R65-R80.

68. Silva J, Nichols J, Theunissen TW, Guo G, Van-Oosten AL, Barrandon O, Wray J, Yamanaka S, Chambers I, Smith A: Nanog is the gateway to the pluripotent ground state. Cell 2009, 138:722-737.

69. Rodda DJ, Chew JL, Lim LH, Loh YH, Wang B, Ng HH, Robson P: Transcriptional regulation of nanog by OCT4 and SOX2. J Biol Chem 2005, 280:24731-24737.

70. Loh YH, Wu Q, Chew JL, Vega VB, Zhang W, Chen X, Bourque G, George J, Leong B, Liu J, Wong KY, Sung KW, Lee CW, Zhao XD, Chiu KP, Lipovich L, Kuznetsov VA, Robson P, Stanton LW, Wei CL, Ruan Y, Lim B, Ng HH: The Oct4 and Nanog transcription network regulates pluripotency in mouse embryonic stem cells. Nat Genet 2006, 38:431-440

71. Chambers I, Tomlison SR: The transcriptional foundation of pluripotency. Development 2009, 136:2311-2322.

72. Caufmann G, Van De-Velde H, Liebaers I, Van-Steirteghem A: Oct4 mRNA and preotein expression during human preimplantation development. Mol Hum Reprod 2005, 11:173-181.

73. Sritanaudomachi H, Sparman M, Tachibana M, Cleper L, Woodward J, Gokhale S, Wolf D, Hennebold J, Hurlbut W, Grompe M, Mitalapov S: CDX2 in the formation of the trophectoderm lineage in primate embryos. Dev Biol 2009, 335:179-187.

74. Guest DJ, Allen WR: Expression of cell-surface antigens and embryonic stem cell pluripotency genes in equine blastocysts. Stem Cells Dev 2007, 16:789-796.

75. Kobolak J, Kiss K, Polgar Z, Mamo S, Rogel-Gaillard C, Tancos Z, Bock I, Baji AG, Tar K, Pirity MK: Promoter analysis of the rabbit POU5F1 gene and its expression in preimplantation stage embryos. BMC Mol Biol 2009, 10:88.

76. Goosens K, Van-Soom A, Van-Poucke M, Vandaele L, Vandesompele J, Van-Zeveren A, Peelman LJ: Identification and expression analysis of genes associated with bovine blastocyst formation. BMC Dev Biol 2007, 7:64.

77. Goosens K, Van-Soom A, Van-Zeveren A, Favoreel H, Peelman LJ: Quantification of Fibronectin 1 (FN1) splice variants, including two novel ones, and analysis of integrins as candidate FN1 receptors in bovine preimplantation embryos. BMC Dev Biol 2009, 9:1.

78. Hesse M, Franz T, Tamai Y, Taketo MM, Magin TM: Targeted deletion of keratins 18 and 19 leads to trophoblast fragility and early embryonic lethality. EMBO J 2009, 19:5060-5070.

79. Yang QE, Fields SD, Zhang K, Ozawa M, Johnson SE, Ealy AD: Fibroblast growth factor 2 promotes primitive endoderm development in bovine blastocyst outgrowths. Biol Reprod 2011, 85:946-953.

80. Sumer H, Liu J, Malaver-Ortega LF, Lim ML, Khodadadi K, Verma PJ: NANOG is a key factor for induction of pluripotency in bovine adult fibroblasts. J Anim Sci 2011, 89:2708-2716.

81. Rogers MB, Hosler BA, Gudas LJ: Specific expression of a retinoic acid-regulated, zinc-finger gene, Rex-1, in preimplantation embryos, trophoblast and spermatocytes. Development 1991 113:815-824.

82. Rugg-Gunn PJ, Cox BJ, Ralston A, Rossant J: Distinct histone modifications in stem cell lines and tissue lineages from the early mouse embryo. Proc Natl Acad Sci U S A 2010, 107:10783-10790.

83. Hublitz $P$, Albert M, Peters AH: Mechanisms of transcriptional repression by histone lysine methylation. Int J Dev Biol 2009, 53:335-354.

84. Pichugin A, Le-Bourhis D, Adenot P, Lehmann G, Audouard C, Renard JP, Vignon X, Beaujean N: Dynamics of constitutive heterochromatin: two contrasted kinetics of genome restructuring in early cloned bovine embryos. Reproduction 2010, 139:129-137.
85. Young DW, Hassan $M Q$, Yang $X Q$, Galindo $M$, Javed $A$, Zaidi SK, Furcinitti $P$, Lapointe D, Montecino M, Lian JB, Stein JL, Van-Wijnen AJ, Stein GS: Mitotic retention of gene expression patterns by the cell fate-determining transcription factor Runx2. Proc Natl Acad Sci U S A 2004, 104:3189-3194.

86. Zaidi SK, Young DW, Montecino M, Van-Wijnen AJ, Stein JL, Lian JB, Stein GS: Bookmarking the genome: maintenance of epigenetic information. J Biol Chem 2011, 286:18355-18361.

doi:10.1186/1471-213X-13-32

Cite this article as: Madeja et al.: Changes in sub-cellular localisation of trophoblast and inner cell mass specific transcription factors during bovine preimplantation development. BMC Developmental Biology 2013 13:32.

\section{Submit your next manuscript to BioMed Central and take full advantage of:}

- Convenient online submission

- Thorough peer review

- No space constraints or color figure charges

- Immediate publication on acceptance

- Inclusion in PubMed, CAS, Scopus and Google Scholar

- Research which is freely available for redistribution 